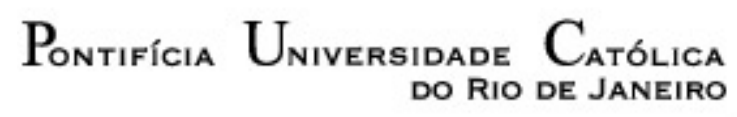

Thaís Cristina Chagas Santos Azevedo

\title{
Business Process Management: a life cycle approach
}

Thesis presented to the Programa de PósGraduação em Engenharia de Produção of the Departamento de Engenharia Industrial, PUC-Rio, as partial fulfillment of the requirements for the degree of Mestre.

Advisor: Prof. Luiz Felipe Roris Rodriguez Scavarda do Carmo Co-advisor: Prof. Bernd Hellingrath 
Thaís Cristina Chagas Santos Azevedo

\section{Business Process Management: a life cycle approach}

Thesis presented to the Programa de Pós-Graduação em Engenharia de Produção of the Departamento de Engenharia Industrial do Centro Técnico Científico da PUC-Rio, as partial fulfillment of the requirements for the degree of Mestre.

Prof. Silvio Hamacher

President Departamento de Engenharia Industrial - PUC-Rio

Prof. Luiz Felipe Roris Rodriguez Scavarda do Carmo Advisor Departamento de Engenharia Industrial - PUC-Rio

Prof. Paula Santos Ceryno Universidade Federal do Estado do Rio de Janeiro - UNIRIO

Prof. Thaís Spiegel Universidade do Estado do Rio de Janeiro - UERJ

Prof. Márcio da Silveira Carvalho Coordinator of the Centro Técnico Científico da PUC-Rio 
All rights reserved.

Thaís Cristina Chagas Santos Azevedo

Thaís Cristina Chagas Santos Azevedo graduated in Industrial Engineering at PUC-Rio in 2014. She joined during two and a half years the NExO - Group of Decision Support and Supply Chain (TECGRAF / PUC-Rio) working in the field of logistics operations.

Bibliographic data

Azevedo, Thaís Cristina Chagas Santos

Business Process Management : a life cycle approach / Thaís Cristina Chagas Santos Azevedo ; advisor: Luiz Felipe Roris Rodriguez Scavarda do Carmo ; co-advisor: Bernd Hellingrath. - 2016.

86 f. : il. ; $30 \mathrm{~cm}$

Dissertação (mestrado)-Pontifícia Universidade Católica do Rio de Janeiro, Departamento de Engenharia Industrial, 2016.

Inclui bibliografia

1. Engenharia Industrial - Teses. 2. Cadeia de suprimentos. 3. Logística. 4. Pesquisa ação. 5. Pesquisa empírica. 6. Gerência de operações. I. Carmo, Luiz Felipe Roris Rodriguez Scavarda do. II. Hellingrath, Bernd. III. Pontifícia Universidade Católica do Rio de Janeiro. Departamento de Engenharia Industrial. IV. Título. 


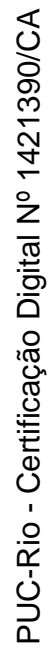

To my familly. 


\section{Acknowledgments}

First, I want to thank my advisor Prof. Luiz Felipe Scavarda for the opportunity to work with him, to his support to my master's course and for believing in me to develop this thesis. I learned a lot in this 2.5 years working under his supervision, considering the indergraduate studies together. I would like to express my gratitude also to my co-advisor Bernd Hellingrath for his ideas, commitment and valuable time to support me in this work. They generously spent their time, patience, and help to guide me making this dissertation possible.

I acknowledge the professors who kindly accepted the invitations to collaborate with their experience for the evaluation of this study.

I am grateful to PUC's professors, staff and my colleagues who shared their time and knowledge with me and $\mathrm{CNPq}$ for the assistance and support during these years of intensive research.

I would like to acknowledge my co-workers at $\mathrm{NExO}$, specially Luiza Fiorencio and Paula Ceryno, who I closely worked with in these 2.5 years and were very important to all the learning acquired by me in these years. I would also like to give a special thank to the company in which the action research was developed and all its logistics employees who have always been solicitous and welcoming.

Furthermore, I would like to thank my friends and boyfriend for their encouragement, support, advice, and understanding.

Last, but not least, I am very grateful to my family, for the constant support during this master's course and for understanding the effort I needed to to finish this work. 


\section{Abstract}

Azevedo, Thaís Cristina Chagas Santos; Carmo, Luiz Felipe Roris Rodriguez Scavarda do (Advisor); Hellingrath, Bernd (Co-advisor). Business Process Management: a life cycle approach. Rio de Janeiro, 2016. 86p. MSc Dissertation - Departamento de Engenharia Industrial, Pontifícia Universidade Católica do Rio de Janeiro.

Business process management (BPM) has obtained significant importance for both academics and practitioners. However, the academic literature needs additional empirical researches to fulfill research-practice gaps, especially on how organizations are developing BPM tasks, identifying the barriers faced and main enablers adopted. Within this context, this paper presents the empirical findings and lessons learnt from an action research on the evolution of the logistics processes management for a multinational entertainment company. Different critical factors are analyzed and discussed within the Master Thesis regarding the entire BPM development from a life cycle approach, focusing in the organizational, people and IT dimensions, resulting in contributions for both academics and practitioners.

\section{Keywords}

Supply Chain; logistics; warehouse; action research; empirical research; operations management. 


\section{Resumo}

Azevedo, Thaís Cristina Chagas Santos; Carmo, Luiz Felipe Roris Rodriguez Scavarda do; Hellingrath, Bernd. Gestão de Processos de Negócios: uma abordagem de ciclo de vida. Rio de Janeiro, 2016. 86p. Dissertação de Mestrado - Departamento de Engenharia Industrial, Pontifícia Universidade Católica do Rio de Janeiro.

A Gestão de Processos de Negócios (em inglês, Business Process Management - BPM) tem obtido uma importância significativa tanto para os acadêmicos quanto para os participantes no mundo industrial. Contudo, um maior número de pesquisas empíricas se faz necessário para preencher uma lacuna existente na literatura acadêmica, especialmente no que diz respeito em como as organizações estão desenvolvendo as tarefas relacionadas à gestão de seus processos, como estão identificando as barreiras enfrentadas nesta gestão e os principais facilitadores usados para superar tais barreiras. Neste contexto, este estudo apresenta os achados empíricos e as lições aprendidas em uma pesquisa-ação sobre a evolução da gestão dos processos logísticos de uma multinacional do ramo de entretenimento que teve duração de aproximadamente dois anos e meio. O estudo contou com a participação de membros da academia, profissionais da organização e consultores externos. A partir da literatura em BPM, foram estudados diversos ciclos de vida da gestão de processos de negócios propostos por distintos autores e um modelo conceitual é proposto para orientar o desenvolvimento das tarefas realizadas na gestão de processos. Diferentes fatores críticos são analisados e discutidos nesta tese de Mestrado a partir da abordagem de ciclo de vida escolhida para a gestão dos processos logísticos da companhia com foco nas dimensões organizacionais, de recursos humanos e da tecnologia da informação da organização, resultando em contribuições tanto para acadêmicos quanto para os profissionais no mercado. 


\section{Palavras-chave}

Cadeia de suprimento; logística; armazém; pesquisa ação; pesquisa empírica; gerência de operações. 


\section{Contents}

1 INTRODUCTION 13

2 THEORETICAL FOUNDATIONS

2.1. Business Process Management (BPM) 15

2.1.1. INTRODUCTION AND BASIC DEFINITIONS 15

2.1.2. THREE LEVELS FOR BPM 18

2.1.3. CRITICAL SUCCESS FACTORS AND MAIN BARRIERS 24

2.2. LIFE CYCLE APPROACH 27

2.2.1. ConcePtuAl FRAMEWORK FOR BPM DEVELOPMENT 33

3 RESEARCH DESIGN

3.1. ORGANIZATION ANALYSIS 43

3.2. DESIGN 44

3.3. IMPLEMENTATION 45

3.4. EXECUTION AND MONITORING 46

3.5. ASSESSMENT 47

4 MAIN FINDINGS AND RESULTS 49

4.1. ORGANIZATION ANALYSIS 49

4.2. DESIGN 52

4.3. IMPLEMENTATION

4.4. EXECUTION AND MONITORING 57

4.5. ASSESSMENT 59

5 DISCUSSIONS

6 CONCLUSIONS 69

REFERENCES $\quad 72$

APPENDIX I: BPM LIFE CYCLE MODELS 81 


\section{List of figures}

Figure 1 - Business Process 16

Figure 2 - Three levels for BPM 19

Figure 3 - The conceptual procedural framework for BPM development 34

Figure 4 - Processes architecture 


\section{List of tables}

Table 1 - Definitions for business process 15

Table 2 - Main critical success factors 25

Table 3 - Main barriers in BPM projects $\quad 27$

Table 4 - Synthesis of BPM life cycle models 29

Table 5 - Synthesis of the main barriers and critical success factors 68 


\section{List of acronyms}

BP - Business Process

BPM - Business Process Management

BPMS - Business Process Management Systems

BPMN - Business Process Modeling and Notation

CSF - Critical Success Factor

EPC - Event-driven Process Chain

ERP - Enterprise Resource Planning

IT - Information Technology

KPI - Key Performance Indicator

PAHM - Process Assessment Heat Map

PDCA - Plan, Do, Check, Act

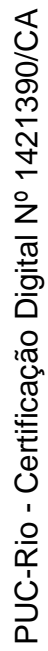

PMS - Performance Measurement System

RFID - Radio-Frequency Identification

$R Q$ - Research Question

SIPOC - Suppliers, Inputs, Process, Outputs, Customers

SOP - Standard Operating Procedure

UML - Unified Modeling Language

WMS - Warehouse Management System 


\section{1 \\ Introduction}

Business processes (BP) are sequences of activities co-ordinately performed within an organization or a supply chain to transform inputs such as materials, information, people or other resources, in outputs that can be goods and services, towards meeting customers' needs and requirements in a way that the business' goals are achieved. The set of actions to identify, design, execute, document, measure, monitor, control and promote improvements in an organization's processes to meet business objectives is termed business process management (BPM) (Morais et al., 2014). BPM involves people, organizations, applications, documents and other sources of information in order to enhance value creation to customers (van der Aalst et al., 2003). It is considered a discipline that integrates information technology (IT) and business process expertise with the goal of transforming-isolated business efforts into integrated and measurable crossfunctional activities that deliver operational and strategic competitive advantages (Antonucci and Goeke, 2011).

Although BPM has been intensely discussed in the academic literature since the late 1980s, empirical research in BPM is still in its infancy being in an early phase of its maturity process (Houy et al., 2010). The increase of empirical research is seen as positive to the development of this research area (Houy et al., 2010), however in a recent state-of-the-art review on the topic, Recker and Mendling (2016) identify the lack of strong empirical research in BPM. This corroborates Singer (2015), which states an existent evident gap between theory and application of BPM supporting the need of empirical studies in the area. These gaps embrace aspects on how organizations develop BPM tasks and the identification of the main critical factors and barriers faced in BPM and the enablers needed to surpass these barriers (Paim et al., 2008; Silva et al., 2012; Škrinjar and Trkman, 2013; Singer, 2015; Buh et al., 2015; Recker and Mendling, 2016). Moreover, Recker and Mendling (2016) also identify a missing maturity in $\mathrm{BPM}$ research related to the coverage of the complete BPM life cycle. 
Within this context, the following research questions (RQs) are put forward:

RQ1 - How should organizations develop BPM from a life cycle approach?

RQ2 - What are the main critical factors and enablers for a successful BPM and how do they act in each phase of the BPM life cycle?

To address the research-practice gap and the RQs, this thesis aims to present the empirical findings and lessons learnt from an action research on the evolution of the logistics processes management for a broadcasting company. The development covers the procedure rather than the structure of the processes offering a conceptual procedural framework with information and insights on how to design, implement, use (execute and monitor) and assess logistics processes. The scope of this thesis does not embrace the aspects related to BPM systems implementation, as well as the aspects involved with the definition of the company's business and applications architectures. The entire research effort lasted almost two and a half years, involving researchers from academia and practitioners from the company. The choice of this research method is relevant, as less than $2 \%$ of the empirical researches in BPM are based on action research (Houy et al., 2010). Moreover, Karatas-Cetin and Denktas-Sakar (2013) identify in their review about the patterns in the evolution of logistics research since 2000 the need of more qualitative researches, especially action research.

This thesis is organized into six chapters, being this first one the introduction. Chapter 2 presents the theoretical foundations. Chapter 3 describes the research design adopted. Chapter 4 presents the case and its main findings and results. In Chapter 5 the main discussions are made. Finally, Chapter 6 offers the author's main conclusions. 


\section{2 \\ Theoretical foundations}

The chapter provides the theoretical background for the action research. First, it presents the main concepts related to BPM and the critical factors and barriers. Next, it presents different life cycle approaches for BPM. The chapter ends with a Conceptual framework for BPM development.

\section{1.}

\section{Business Process Management (BPM)}

This section is divided into three main parts, being the first one an introduction to BPM. A three level model for BPM is presented next and finaly; the section presents the critical success factors and main barriers for BPM.

\subsection{1. Introduction and basic definitions}

The literature offers many definitions for Business Process, as exposed in Table 1.

Table 1 - Definitions for business process

\begin{tabular}{|c|c|}
\hline Definition & Reference \\
\hline $\begin{array}{l}\text { Any activity that receives an input and using the organization's } \\
\text { resources, generates a certain output for an internal or external } \\
\text { client }\end{array}$ & Harrington (1993) \\
\hline $\begin{array}{l}\text { Sequence of pre-defined activities executed to achieve a pre- } \\
\text { specified type or range of outcomes }\end{array}$ & Talwar (1993) \\
\hline $\begin{array}{l}\text { Strands of activity that link the operations of an organisation to the } \\
\text { requirements of its customers }\end{array}$ & $\begin{array}{l}\text { IMI (1994, apud Lee and } \\
\text { Dale, 1998) }\end{array}$ \\
\hline $\begin{array}{l}\text { Sequence of executions in a business context based on the purpose } \\
\text { of creating goods and services }\end{array}$ & Scheer and Nüttgens (2000) \\
\hline $\begin{array}{l}\text { Sequence of activities that is necessary to manipulate an object of } \\
\text { economic interest to the organization, and that achieves a specific } \\
\text { goal }\end{array}$ & Zur Muehlen and Ho (2005) \\
\hline $\begin{array}{l}\text { Set of activities that is performed in coordination in an } \\
\text { organizational and technical environment }\end{array}$ & Weske (2012) \\
\hline $\begin{array}{l}\text { A set of structured and measured activities designed to produce a } \\
\text { specified outcome for a defined customer or market }\end{array}$ & Davenport (2013) \\
\hline
\end{tabular}


In synthesis, business process can be understood as the sequence of activities coordinately performed in an organization or a supply chain to transform inputs (e.g., materials, information, people or other resources) in outputs (e.g., goods and services) that meet the needs and requirements of the customers, in a way that objectives of the organization are met. Figure 1 illustrates this understanding.

Figure 1 - Business Process

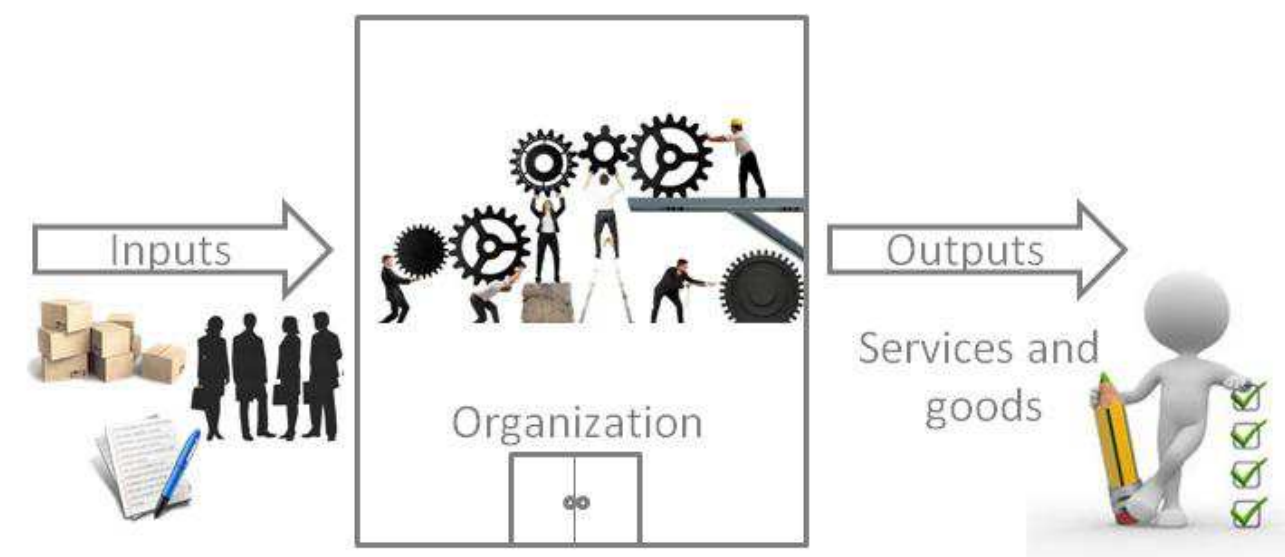

Source: Author.

Process management is "an integrated organizational capability that manifests itself through a set of mutually supportive routines and practices in order to exploit existing processes and explore new processes" (Ng et al., 2015). It aims to facilitate communication and cooperation, bridging strategies, organizational capabilities and daily activities (de Boer et al., 2015). Process management is both a technique and a tool with which workers in organizations seek to improve their processes to achieve their goals (Lee and Dale, 1998).

Process management tasks must consider how the following elements relate to processes (Paim et al., 2008):

- Strategy, culture and values (Porter, 1985; Schein, 2006);

- Information and knowledge (Hlupic, 2002; Nonaka, 2008; Davenport, 2013);

- Innovation and improvement (Shingo, 1989; Deming, 1990; Goldratt, 1990; Davenport, 2013);

- Information technology (Davenport, 2013); 
- People and competences (Nonaka, 2008; Spanyi, 2010);

- Performance indicators and incentive mechanisms (Kaplan and Norton, 2006; Rummler and Brache, 2012);

- Budgeting and costs (Goldratt, 1990; Kaplan and Norton, 1996);

- Norms and procedures (Deming, 1990; Campos, 1996);

- Control and audit (Grover and Kettinger, 2000);

- Division and coordination of work (Galbraith, 2000; Hayashi and Herman, 2002);

- $\quad$ Products and production systems (Ohno, 1988; Shingo, 1989).

BPM is a formal methodology of process management and can be defined as a set of methods, techniques and tools to analyze, improve, innovate, design, enact and control business processes involving customers, humans, organizations, applications, documents and other sources of information in order to facilitate an optimized value creation (van der Aalst et al., 2003). It aligns process with the organization's strategic goals, designing and implementing process architectures, establishing process measurement systems that are in accordance with organizational goals, and educating and organizing managers so that they will manage processes effectively (Harmon, 2004). BPM is also viewed as a systematic and structured approach to continually improve fundamental activities such as manufacturing, marketing, communications and other major elements of a company's operations with the aim of improving the quality of products and services (Elzinga et al., 1995; Zairi and Sinclair, 1995; Zur Muehlen and Ho, 2005). Experts agree that BPM evolved from a system orientation to a management practice in which companies have its process-centric and customerfocused organization, with goals, people and technology integrated in the operational and strategic activities (Silva et al., 2012).

There are three main group of tasks necessary for organizations to have inhouse BPM practice: (i) projecting process, (ii) day-to-day processes management, and (ii) promoting evolution and learning (Paim et al., 2008), as described next.

The projecting process tasks encompass the understanding of the environment in which the organization is inserted and its internal environment in relation to its business strategy. The establishment for a change management 
approach and ensuring the sponsorship for change are also necessary. Teams are formed to understand, select, and prioritize processes and tools. Processes are modeled in the current situation, solutions to current problems are prioritized, management practices are defined, processes in the future are understood and modeled and the needed process changes are defined (Silva et al., 2012).

The day-to-day processes management tasks involve changes implementation, processes realization, monitoring and controling of the processes execution, and perform short-term changes (Silva et al., 2012).

The third group of tasks is formed by activites that promote evolution and learning and is based on the understanding of the evolution trajectory of the processes through actions that increase process predictability, which means understanding the relation between the promised performance and the one achieved to be able to deliver what was promised. Recording of processes performance, controlling the deviations of the processes efficiency and perform the benchmarking process are some of the activities performed in this third group of tasks (Silva et al., 2012).

\subsection{2.}

\section{Three levels for BPM}

The different projects or activities involved in BPM require different participants, different methodologies and different types of support at different levels of concern. These levels are three: (i) enterprise level, (ii) business process level and (iii) implementation or resource level of concern. As companies become more mature in their process management, they work simultaneously in all the three mentioned levels (Harmon, 2014). Figure 2 presents the levels, which are described afterwards. 
Figure 2 - Three levels for BPM

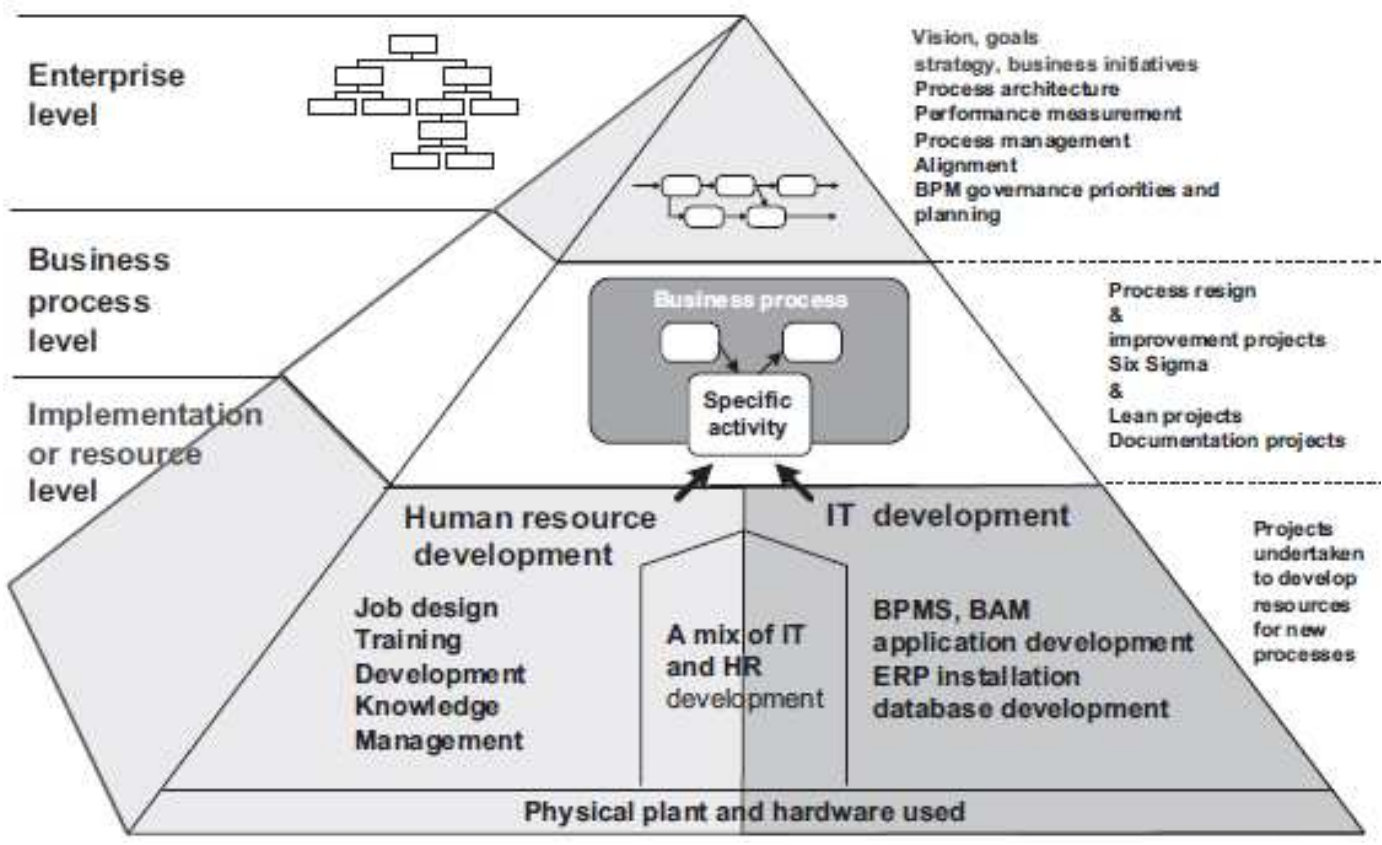

Source: Harmon (2014).

\subsubsection{1. Enterprise level}

The activities and initiatives in the enterprise level are related to (i) the alignment of the processes with the organization strategy and, (ii) the definition of the business architecture, (iii) the process governance and (iv) the measurement systems (Harmon, 2014).

The prime role of BPM at this level is to ensure that the various developed organization capabilities are aligned with one another and together they deliver traceable process performance back to the stated strategic goals and objectives (Burlton, 2010). Only a tight alignment with the organizational strategy can ensure the relevance of BPM and a valuable contribution to the corporate longterm priorities. Successful BPM can also shape corporate strategy when improved process performance provides an opportunity to become a competitive differentiator (vom Brocke and Rosemann, 2010).

The Business Architecture is the result of defining the business strategies, processes, and functional requirements (Pereira and Sousa, 2004). Business Architecture defines how the business is organized to achieve its goals and, that "the business process architecture method is concerned with creating tools that a 
company can use to organize and manage all its process work" (Harmon, 2014, p.53). It is the base for identifying the requirements for information systems, which support the business activities (Pereira and Sousa, 2004). "A business architecture defines the major processes in a value chain, establishes their relationships, defines their performance measures, determines who manages each process, and describes how the processes are aligned to other organizational resources, including, for example, goals and policies, business rules, IT resources, training programs, and knowledge-management systems" (Harmon, 2014, p.26).

Business Process Frameworks, also called Operation Reference Frameworks (as the Supply Chain Council's SCOR Framework and the Value Reference Model), provide a quick way for a company to establish a high-level process architecture, complete with core, management and support processes, and with measures to use in evaluating performance (Harmon, 2010). There was an increase in the last years in the number of industry and specific value chain frameworks or reference models that articulate a set of best practices for viewing and managing the work of organizations. Nevertheless, not always these frameworks and models are relevant due to the peculiar nature of the business and should only serve the purpose of providing a starter kit or a point of comparison for organizations that want a consistent way of evaluating themselves against a benchmark (Burlton, 2010).

The BPM governance creates the structures, metrics, roles and responsibilities to measure and manage the companies' processes performance (Spanyi, 2010). The process governance is important in all stages of the process life cycle, from design to assessment, to both inter or intra-organizational processes (Markus and Jacobson, 2010).

The struggle faced by business process practitioners is to define process measurement systems that are able to determine if the processes are functioning efficiently and if the processes are contributing to the company success (Harmon, 2010). The scorecard systems are becoming a popular approach to define and record the process measures, but the challenge is to create a system that aligns the measures from the top to the bottom of the company (Harmon, 2010). Burlton (2010) identifies the steps to define the performance measurement system as: (i) to identify those performance indicators to be used in each process; (ii) to 
associate the indicators in process architecture with the strategic objectives and satisfaction measures for all stakeholders, while prioritizing changed processes; (iii) to determine the traceability of measures throughout the value chain; and finally (iv) to identify which measures appear in the processes caused by other processes executed previously.

Finally, the corporate culture can increase organizational effectiveness because culture controls the way members make decisions, the way they interpret and manage the organizational environment, what they do with information, and how they behave (Bulander and Dietel, 2013). The business culture incorporates the values and beliefs that guide the company in your process management (de Boer et al., 2015). For instance, a successful transformation of a company to a more process focused orientation involves many changes in the organization culture and the involvement of the top management executives (Harmon, 2014). There are four distinct cultural values that facilitate BPM (vom Brocke and Sinnl, 2011; Schmiedel et al., 2013): customer orientation (focus on customers as the driver and goal of business processes), excellence (focus on continuous improvement, innovation, leanness, and quality), responsibility (focus on commitment, inner engagement, duty), and teamwork (focus on cross-functional orientation rather than functional departments).

\subsubsection{2. \\ Business Process level}

The second level is the business process level. The activities and initiatives in this level relate with the creation, redesign or improvement of specific business processes. Methodologies and tools used in process analysis and redesign, as lean and six sigma projects, are associated to this level (Harmon, 2014).

Process models are used to communicate a message, to share knowledge or vision, as a starting point for redesigning or optimizing processes, or as precise instructions for executing business tasks (Polyvyanyy et al., 2015). Business process modeling is essential to understand and in the redesign of the activities performed by a company to achieve its business goals. Moreover, the quality of business process models impact on the quality of (the design of) information systems and on envisaged business process improvements (de Oca et al., 2015). 
"The most important practical distinction in process modeling is between the relatively informal diagrams that business managers use to help them understand processes and the relatively formal diagrams that IT software developers use to specify exactly how a software program might implement the process" (Harmon, 2014, p.215).

Process flow diagrams, also called process maps, activity diagrams and workflow diagrams, are used to describe processes and many different diagramming notations have been used by practitioners (Harmon, 2014). The exact notation used by a company is not so important, however the notation should be used consistently (Harmon, 2014). Different notations for modeling business processes are available, since simple Petri nets to BPMN (Business Process Modeling and Notation), UML (Unified Modeling Language) activity diagrams, EPCs (Event-driven Process Chains) and Proprietary Notations (Lautenbacher et al., 2008; Tka and Ghannouchi, 2012).

The academic and grey literatures offer many methods, tools and techniques to support BP modeling, analysis and improvement. SIPOC (Suppliers, Inputs, Process, Outputs, Customers), SOP (Standard Operating Procedure), PDCA (Plan, Do, Check, Act), and cause and effect diagram (also known as Ishikawa or fishbone diagram) are some examples of these tools and techniques. A SIPOC diagram is a high-level picture of a process and is used as a tool to identify all relevant elements of a process improvement project before it starts. The tool name prompts to consider the Suppliers of a process, the Inputs to the process, the Process that is being improved, the Outputs of the process, and the Customers that receive the process outputs (Montevechi et al., 2008). SOP is a standard operating procedure is a set of instructions having the force of a directive, covering those features of operations that lend themselves to a definite or standardized procedure without loss of effectiveness (Mission, 2008). PDCA is a continuous feedback loop to identify and change process elements aiming to reduce the process variation. In other words, the PDCA's objective is to plan to do something, manufacture or do it, check it for meeting requirements, and correct the process to maintain the acceptable output performance (Gupta, 2006). The cause and effect diagram graphically exhibits the relationships between a particular outcome 
(effect) and all of the identified possible causes that contribute to that outcome (McCormick, 2002).

\subsubsection{3. Implementation or resource level}

At third level is the implementation or resource level of concern. In this level, the activities and initiatives are undertaken to develop and support resources for the processes. At this level IT development is essential. Human resource development also plays and important rule through initiatives as job design, knowledge management and training development. A mix of both is required and the physical plan and the hardware used should be considered (Harmon, 2014).

According to Grudzewski and Hedjuk (2002, apud Bitkowska, 2015), knowledge is information applied in practice and Bitkowska (2015) states knowledge management as a deliberate and systematic approach to ensure the use of the organization's knowledge basis towards a better efficiency. The knowledge creation in BPM contributes to increasing the process efficiency of an organization and thereby the organizational effectiveness. The former approach involves the measurement of the process effectiveness through data collection and then data analysis and interpretation. In this way, knowledge is created and used to improve processes (Bitkowska, 2015).

Training is a planned and systematic endeavor that happens through learning experiences and aims to modify or develop knowledge, skills and behavior towards the achievement of an effective performance in an activity or a group of activities (Garavan, 1997). In this meaning, training is essential to a better performance of the processes' effectiveness.

BPM and IT management are tightly integrated. An IT management and development process-oriented ensures alignment of IT decisions and applications with business objectives and provides better support to business processes. Because of these interdependencies, many studies emphasize the IT involvement in BPM activities as well as the other way around (Rahimi et al., 2016). Software tools supporting the management of business processes are known as Business Process Management Systems (BPMS) (Ko et al., 2009) and it should present the 
needed flexibility, support process improvement initiatives and support the information exchange across departments (Willaert et al., 2007).

\subsection{3.}

\section{Critical success factors and main barriers}

The literature in BPM also discusses the critical success factors (CSF) in BMP projects. According to Bandara et al. (2009) success factors are key areas where "things must go right" in BPM initiatives, allowing the efficient implementation. Successful completeness of the project and companies should consider different CSFs at different phases of BPM life cycle (as seen in the 2.2 section) and not just focus in one small group of CSFs (Buh et al., 2015). For the propose of this research, the following critical factors are adopted based on categories from Škrinjar and Trkman (2013), Bai and Sarkis (2013) and Buh et al. (2015): strategic alignment, top management support, information technology, collaborative communication, culture, training and empowerment of the employees, performance measurement, project management, user focus, and methods or methodology. Depending of their lack or presence in the projects, the CSF can be treated as a barrier or as an enabler to the success of the initiatives (Santos et al., 2015). Table 2 presents a synthesis of main critical factors of BPM with a description of each of them and the references associated to each factor. Table 3 presents the main barriers that are present in BPM and the references associated to each barrier. One of the aspects to be investigated in empirical studies isn't only what are the CSFs need to be present in the BPM project to its success but also what are the practices related to the CSFs that are perfomed during the BPM and that guarantee the success of the initiatives. 
Table 2 - Main critical success factors

\begin{tabular}{ll}
\hline Critical factors & Description \\
\hline Strategic alignment & $\begin{array}{l}\text { Refers to the alignment of the process with the organizational organizations goals, } \\
\text { resulting in the achievement of long-term benefits (Bandara et al., 2009). }\end{array}$
\end{tabular}
support

Information

Technology

Collaborative

environment,

communication

Culture

Training and empowerment of the employees

(Bai and Sarkis, 2013). It has to drive, monitor and control the changes in the organization. It should establish a transformation vision, clearly state the management commitment to the employees and establish the management stability during the project implementation (Bandara et al., 2007).

IT suites should have focus on process and should have the ability to provide relevant information about process efficiency to managers (Trkman, 2010). The proper use of the IT capabilities and the improvement of the IT departments to give the proper support to the development of new tools are also important actions (Bandara et al., 2007)

Intraorganizational cross-functional communication in organizations facilitates the mutual understanding and congruence of the organization's strategic direction and goals. (Bai and Sarkis, 2013). Effective communication channels between all the stakeholders of the process and a strong sense of trust within the employees are important components of a collaborative environment (Bandara et al., 2007).

Regards to values and beliefs that the organization incorporates in order to be more process-centered (Bai and Sarkis, 2013). A successful BPM Project needs formalism in processes and business planning, propensity to change and to innovate and to encourage higher levels of collaboration (Bandara et al., 2009).

Employees should understand the entire process and their inter-process linkages and not just their individual activities. They should know how their individual processes contribute to the organizational goals. Employees also need to be trained in the changes

\section{References}

Ariyachandra and Frolick (2008); Ngai et al. (2008); Bandara et al. (2009); Thompson et al. (2009); Trkman (2010); vom Brocke and Rosemann (2010); Ravesteyn and Batenburg (2010); Ohtonen and Lainema (2011); Škrinjar and Trkman(2013); Rosemann and vom Brocke (2015).

Ngai et al. (2008); Žabjek et al. (2008); Bandara et al. (2009); Ohtonen and Lainema (2011); Ravesteyn and Batenburg (2010); Trkman (2010); Škrinjar and Trkman(2013). implemented in processes and in the IT suites used (Škrinjar and Trkman, 2013).
Ngai et al. (2008); Žabjek et al. (2008); Bandara et al. (2009); Thompson et al. (2009); Trkman (2010); Ohtonen and Lainema (2011); Ringim et al. (2012); Rosemann and

Ariyachandra and Frolick (2008); Ngai et al. (2008); Žabjek et al. (2008); Bandara et al. (2009); Thompson et al. (2009); Trkman (2010); Ravesteyn and Batenburg (2010); Ohtonen and Lainema (2011); Škrinjar and Trkman (2013)

Ngai et al. (2008); Bandara et al. (2009); Thompson et al. (2009); Ravesteyn and Batenburg (2010); Ohtonen and Lainema (2011); Rosemann and vom Brocke (2015).

Bandara et al. (2009); Thompson et al. (2009); Ravesteyn and Batenburg (2010); Trkman (2010); Ohtonen and Lainema (2011); Ringim et al. (2012); Škrinjar and Trkman (2013). vom Brocke (2015) 


\section{Critical factors}

Performance

measurement

Project management

Method /

methodology

\section{User focus}

\section{Description}

Performance measurement systems should control and assess the performance of the processes. They should also feed the review of the processes aiming processes improvement (Bai and Sarkis, 2013).

It consists of establishing and planning activities that make it possible to ensure that the implementation processes are rationally managed. It establishes a suitable team to implement, monitor and control the project (Bai and Sarkis, 2013).

Every process has a user (customer) that might be either internal or external to the organization. BPM is as a major management approach that improves user service by redesigning the workflows improving both user service efficiency and effectivenes (Bai and Sarkis, 2013).

It is the set of procedures, techniques and tools developed to lead a business process effort to the success and decrease the problems and difficulties during the life cycle of the project (Bandara et al., 2009).

\section{References}

Bandara et al. (2009); Ravesteyn and Batenburg (2010);

Trkman (2010).

Ariyachandra and Frolick (2008); Ngai et al. (2008); Bandara et al. (2009); Žabjek et al. (2008); Ohtonen and Lainema (2011); Trkman (2010); Škrinjar and Trkman (2013); Rosemann and vom Brocke (2015).

Ngai et al. (2008); Bandara et al. (2009); Ravesteyn and Batenburg (2010); Rosemann and vom Brocke (2015).

Bandara et al. (2009); Thompson et al. (2009); Ravesteyn and Batenburg (2010) 
Table 3 - Main barriers in BPM projects

\begin{tabular}{|c|c|}
\hline Barriers & Reference \\
\hline $\begin{array}{lccc}\begin{array}{l}\text { Lack } \\
\text { executives/leaders }\end{array} & \text { support } & \text { from } & \text { senior } \\
\end{array}$ & $\begin{array}{l}\text { Baker and Maddux (2005); Silva et al. (2012); } \\
\text { Chong (2014); Rosemann and vom Brocke (2015). }\end{array}$ \\
\hline $\begin{array}{l}\text { Absence of a cross-functional mindset and a } \\
\text { process manager profile amongst senior } \\
\text { executives }\end{array}$ & $\begin{array}{l}\text { Smith and Fingar (2003); Baker and Maddux } \\
\text { (2005); Valença et al. (2013). }\end{array}$ \\
\hline $\begin{array}{l}\text { Lack of clarity on a strategic level of the } \\
\text { project }\end{array}$ & $\begin{array}{l}\text { Smith and Fingar (2003); Harmon (2004); Baker } \\
\text { and Maddux (2005); Silva et al. (2012); } \\
\text { Rosemann and vom Brocke (2015). }\end{array}$ \\
\hline $\begin{array}{l}\text { Poor knowledge of process-oriented } \\
\text { approaches }\end{array}$ & $\begin{array}{l}\text { Smith and Fingar (2003); Harmon (2004); Baker } \\
\text { and Maddux (2005); Chong (2014); Rosemann } \\
\text { and vom Brocke (2015). }\end{array}$ \\
\hline Lack of IT expertise & $\begin{array}{l}\text { Smith and Fingar (2003); Chong (2014); } \\
\text { Rosemann and vom Brocke (2015). }\end{array}$ \\
\hline Lack of adequate IT infrastructure & $\begin{array}{l}\text { Smith and Fingar (2003); Zur Muehlen and Ho } \\
\text { (2005); Valença et al. (2013); Rosemann and vom } \\
\text { Brocke (2015). }\end{array}$ \\
\hline $\begin{array}{l}\text { Lack of methodological rigor in execution of } \\
\text { the project }\end{array}$ & $\begin{array}{l}\text { Silva et al. (2012); Rosemann and vom Brocke } \\
\text { (2015). }\end{array}$ \\
\hline $\begin{array}{l}\text { Resistance from employees and stakeholders } \\
\text { to perform the changes implemented }\end{array}$ & $\begin{array}{l}\text { Lee and Dale (1998); Grover (1999); Zur Muehlen } \\
\text { and Ho (2005); Rosemann and vom Brocke } \\
\text { (2015). }\end{array}$ \\
\hline $\begin{array}{l}\text { Lack of a process-orientation culture and } \\
\text { culture change }\end{array}$ & $\begin{array}{l}\text { Zur Muehlen and Ho (2005); Silva et al. (2012); } \\
\text { Valença et al. (2013); Rosemann and vom Brocke } \\
\text { (2015). }\end{array}$ \\
\hline $\begin{array}{l}\text { Concurrence of BPM activities with non- } \\
\text { BPM routine }\end{array}$ & Valença et al. (2013). \\
\hline Implementation delay of modeled processes & Valença et al. (2013). \\
\hline BPM team turnover & $\begin{array}{l}\text { Zur Muehlen and Ho (2005); Valença et al. } \\
\text { (2013). }\end{array}$ \\
\hline $\begin{array}{l}\text { Lack of BPM roles and responsibilities } \\
\text { definition }\end{array}$ & Valença et al. (2013). \\
\hline Lack of priority of systems integration & $\begin{array}{l}\text { Zur Muehlen and Ho (2005); Valença et al. } \\
\text { (2013). }\end{array}$ \\
\hline $\begin{array}{l}\text { A large number of stakeholders with } \\
\text { different perceptions without consensus }\end{array}$ & Zur Muehlen and Ho (2005); Silva et al. (2012). \\
\hline The diversity profile of customers served & Silva \\
\hline Lack of organizational learning development & Silva et al. (2012). \\
\hline
\end{tabular}

\section{2.}

\section{Life cycle approach}

One of the interpretations of the term BPM is an approach that focus in the process life cycle to manage and improve the processes in a continuous transformation with several phases. The use of the life cycle is a generic and systematic approach possible and preferable to BPM and many authors offers different life cycles and different phases descriptions (de Bruin and Doebeli, 2010; Houy et al., 2010). Table 4 presents a synthesis of BPM life cycle models 
considering the number of phases. The table was based in the works of Houy et al. (2010) and Morais et al. (2014) who have maded a systematic review of the life cycle models presented in the literature and one more model. The phases are organized in organizational analysis, design, implementation, execution, monitoring \& controlling, assessment \& improvement. A brief description of the considered phases of each model is also offered in Table 4. The model representation of each model is presented in Appendix I.

All approaches from Table 4 are very similar and procedural in essence guiding into the main steps on BPM development. Most of the models have the sequence from design to assessment and improvement, varying however with the intermediate phases. Some are more detailed than others, but do share a common understanding. The main difference among the models is the inclusion (or not) of an organizational analysis that would serve as a trigger to the before mentioned sequence of phases. The models that present this preliminary phase have their origins in management projects and discussions while the models that do not present this phase have their origins in IT focused projects. 
Table 4 - Synthesis of BPM life cycle models

\begin{tabular}{|c|c|c|c|c|c|c|c|}
\hline Reference & $\begin{array}{c}\text { \# of } \\
\text { phases }\end{array}$ & $\begin{array}{l}\text { Organizational } \\
\text { analysis }\end{array}$ & Design & Implementation & Execution & $\begin{array}{l}\text { Monitoring \& } \\
\text { Controlling }\end{array}$ & Assessment \& improvement \\
\hline $\begin{array}{l}\text { van der Aalst } \\
\text { et al. (2003) }\end{array}$ & 4 & - & $\begin{array}{l}\text { Process design } \\
\text { incorporates "as-is" } \\
\text { modeling processes } \\
\text { into BPMS }\end{array}$ & $\begin{array}{l}\text { System configuration } \\
\text { configures the BPMS and } \\
\text { system infrastructure }\end{array}$ & \multicolumn{2}{|c|}{$\begin{array}{l}\text { Process enactment modeled business } \\
\text { process at deployed in BPMS engines }\end{array}$} & $\begin{array}{l}\text { Diagnosis with identification } \\
\text { and improvement of the } \\
\text { processes after the appropriate } \\
\text { result analysis obtained from } \\
\text { the monitoring tools }\end{array}$ \\
\hline $\begin{array}{l}\text { Zur Muehlen } \\
\text { and Ho (2005) }\end{array}$ & 5 & $\begin{array}{l}\text { Regards to the } \\
\text { definition } \\
\text { organizational of } \\
\text { process goals and } \\
\text { assessment } \\
\text { environmental factors } \\
\text { and constraints that } \\
\text { effect the business } \\
\text { processes. }\end{array}$ & $\begin{array}{l}\text { Identifies the } \\
\text { processes that the } \\
\text { organization wants } \\
\text { to analyze, redesign } \\
\text { and/or automate. } \\
\text { The details of the } \\
\text { processes are } \\
\text { specified and } \\
\text { mapped using } \\
\text { modeling methods. }\end{array}$ & $\begin{array}{l}\text { Processes models are } \\
\text { implemented into the } \\
\text { operational environment } \\
\text { (which can be automated or } \\
\text { not). }\end{array}$ & \multicolumn{2}{|c|}{$\begin{array}{l}\text { Process are executed and monitored in } \\
\text { real time to control the performance. }\end{array}$} & $\begin{array}{l}\text { Audit trails produced during } \\
\text { the enactment and monitoring } \\
\text { stages can be used in the } \\
\text { evaluation stage. Feedbacks } \\
\text { and contingency plans can be } \\
\text { formulated based on the results } \\
\text { of process measurement and } \\
\text { evaluation to improve the } \\
\text { processes. }\end{array}$ \\
\hline $\begin{array}{l}\text { Netjes et al. } \\
(2006)\end{array}$ & 5 & - & $\begin{array}{l}\text { Defines the process } \\
\text { structure, resource } \\
\text { structure, resource } \\
\text { allocation logic and } \\
\text { interfaces among } \\
\text { collaborators by } \\
\text { experimenting and } \\
\text { evaluating designs }\end{array}$ & $\begin{array}{l}\text { Configures the detailed } \\
\text { specification of process } \\
\text { designs with an emphasis on } \\
\text { their realization }\end{array}$ & $\begin{array}{l}\text { Execution involves } \\
\text { the } \\
\text { operationalization of } \\
\text { the configured work } \\
\text { flow; }\end{array}$ & $\begin{array}{l}\text { It controls and } \\
\text { monitors } \\
\text { execution at } \\
\text { the process } \\
\text { performance } \\
\text { level and at the } \\
\text { activities level; }\end{array}$ & $\begin{array}{l}\text { Diagnosis: providing } \\
\text { information for identifying } \\
\text { opportunities for improvement, } \\
\text { such as workflow bottlenecks } \\
\text { and other eventual critical } \\
\text { points. }\end{array}$ \\
\hline $\begin{array}{l}\text { Kannengiesser } \\
(2008)\end{array}$ & 4 & - & $\begin{array}{l}\text { It models existing } \\
\text { "as-is" or future } \\
\text { business processes. }\end{array}$ & $\begin{array}{l}\text { It provides and prepares the } \\
\text { systems to carry out the } \\
\text { business process. Systems } \\
\text { can include employees and } \\
\text { software. }\end{array}$ & $\begin{array}{l}\text { It realizes the actual } \\
\text { instantiated process } \\
\text { using the models } \\
\text { and configurations } \\
\text { produced by the } 1 \mathrm{st} \\
\text { two stages. }\end{array}$ & $\begin{array}{l}\text { It monitors, ana } \\
\text { process and feed } \\
\text { stage. }\end{array}$ & $\begin{array}{l}\text { lyses and validates the actual } \\
\text { ls the results back to the design }\end{array}$ \\
\hline
\end{tabular}




\begin{tabular}{|c|c|c|c|c|c|c|}
\hline Reference & $\begin{array}{c}\text { \# of } \\
\text { phases }\end{array}$ & $\begin{array}{l}\text { Organizational } \\
\text { analysis }\end{array}$ & Design & Implementation & $\begin{array}{l}\text { Monitoring \& } \\
\text { Controlling }\end{array}$ & Assessment \& improvement \\
\hline $\begin{array}{l}\text { Hallerbach et } \\
\text { al. (2008) }\end{array}$ & 4 & - & $\begin{array}{l}\text { It models the } \\
\text { variations of } \\
\text { processes and their } \\
\text { relationships are } \\
\text { identified. }\end{array}$ & $\begin{array}{l}\text { Instantiation/Selection: } \\
\text { configuration or selection of } \\
\text { variations according to the } \\
\text { context. }\end{array}$ & 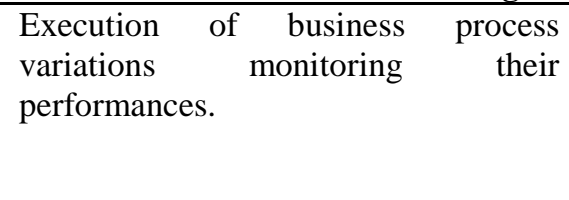 & $\begin{array}{l}\text { Optimization: identifying "best } \\
\text { practices" and evolving } \\
\text { processes. }\end{array}$ \\
\hline $\begin{array}{l}\text { ABPMP }(2009 \text {, } \\
\text { apud Morais et } \\
\text { al., 2014) }\end{array}$ & 6 & $\begin{array}{l}\text { 1-Planning and } \\
\text { strategy: project scope, } \\
\text { roles and } \\
\text { responsibilities, } \\
\text { resources, technology, } \\
\text { tools and feasibility } \\
\text { studies are defined. } \\
\text { 2-Analysis: aimed at } \\
\text { aligning business } \\
\text { objectives with their } \\
\text { processes, whether to } \\
\text { establish or update } \\
\text { them, and techniques } \\
\text { are applied to map the } \\
\text { business context } \\
\text { through interviews, } \\
\text { documental analysis, } \\
\text { simulations or other } \\
\text { instruments of } \\
\text { prospection. }\end{array}$ & $\begin{array}{l}\text { Design and } \\
\text { modeling involves } \\
\text { the creation of new } \\
\text { specifications for } \\
\text { them, their activities } \\
\text { and tasks, rules and } \\
\text { definitions for } \\
\text { exchanging } \\
\text { information among } \\
\text { functional groups } \\
\text { (handoffs, physical } \\
\text { design and IT } \\
\text { infrastructure. }\end{array}$ & $\begin{array}{l}\text { Implementation should be } \\
\text { viewed as an } \\
\text { "orchestration" activity and } \\
\text { it involves training, metric } \\
\text { policies and performance } \\
\text { evaluation, strategic } \\
\text { alignment evaluation and } \\
\text { risk analysis and } \\
\text { monitoring. }\end{array}$ & $\begin{array}{l}\text { Monitoring and controlling deals with } \\
\text { adjustments of resources to ensure } \\
\text { process objectives through } \\
\text { performance measurements and } \\
\text { evaluation. }\end{array}$ & $\begin{array}{l}\text { Refinement is associated with } \\
\text { organizational change, } \\
\text { continuous improvement and } \\
\text { optimization activities in } \\
\text { search of the efficiency and } \\
\text { effectiveness of processes } \\
\text { implemented in the } \\
\text { organization. }\end{array}$ \\
\hline
\end{tabular}




\begin{tabular}{|c|c|c|c|c|c|c|c|}
\hline Reference & $\begin{array}{c}\text { \# of } \\
\text { phases }\end{array}$ & $\begin{array}{l}\text { Organizational } \\
\text { analysis }\end{array}$ & Design & Implementation & Execution & $\begin{array}{l}\text { Monitoring \& } \\
\text { Controlling }\end{array}$ & Assessment \& improvement \\
\hline Verma (2009) & 7 & $\begin{array}{l}\text { 1- Define organization } \\
\text { objectives; } \\
2-\text { Identify } \\
\text { organizational } \\
\text { processes; } \\
\text { 3- Classify processes: } \\
\text { rank processes } \\
\text { according to } \\
\text { contribution criteria for } \\
\text { organizational } \\
\text { objectives, providing } \\
\text { related benchmarks } \\
\text { and potential for } \\
\text { financial improvement. }\end{array}$ & $\begin{array}{l}\text { 1- Select } \mathrm{n} \text { process: } \\
\text { choose the process } \\
\text { that has the best } \\
\text { contribution } \\
\text { 2- Define tools: } \\
\text { determine the use of } \\
\text { the most appropriate } \\
\text { tool, whether it is for } \\
\text { incremental or } \\
\text { radical change. }\end{array}$ & Implementation of the improy & ement project. & Monitoring. & - \\
\hline $\begin{array}{l}\text { Houy et al. } \\
\text { (2010) }\end{array}$ & 6 & $\begin{array}{l}\text { Strategy development } \\
\text { regarding } \\
\text { management } \\
\text { business process. }\end{array}$ & $\begin{array}{l}\text { Definition and } \\
\text { modeling of relevant } \\
\text { processes. }\end{array}$ & $\begin{array}{l}\text { Implementation of processes } \\
\text { in an organization. }\end{array}$ & $\begin{array}{l}\text { Execution } \\
\text { implemented } \\
\text { processes. }\end{array}$ & $\begin{array}{l}\text { Monitoring } \\
\text { and controlling } \\
\text { of the process } \\
\text { execution. }\end{array}$ & $\begin{array}{l}\text { Optimization and improvement } \\
\text { of processes }\end{array}$ \\
\hline $\begin{array}{l}\text { Rosemann } \\
\text { (2010) }\end{array}$ & & $\begin{array}{l}1 \text { - Awareness and } \\
\text { understanding of BPM: } \\
\text { organisation recognises } \\
\text { the value of BPM. } \\
2-\text { Desire to adopt } \\
\text { BPM: a driver and a } \\
\text { champion should have } \\
\text { influence in the } \\
\text { organization to accept } \\
\text { the BPM adoption. }\end{array}$ & $\begin{array}{l}\text { 1- BPM projects: proce } \\
\text { and training, executing } \\
2 \text { - BPM program: ove } \\
\text { roadmap for its execut }\end{array}$ & $\begin{array}{l}\text { ess modeling, improvement, se } \\
\text { and monitoring. } \\
\text { erall BPM methodology is desi } \\
\text { ion. }\end{array}$ & $\begin{array}{l}\text { ting up together with } \mathrm{BI} \\
\text { ned, along with the BPI }\end{array}$ & $\begin{array}{l}\text { PM education } \\
\text { M strategy and a }\end{array}$ & $\begin{array}{l}\text { Productisation of BPM: realise } \\
\text { the overall benefits of adopting } \\
\text { BPM. }\end{array}$ \\
\hline
\end{tabular}


PUC-Rio - Certificação Digital № 1421390/CA

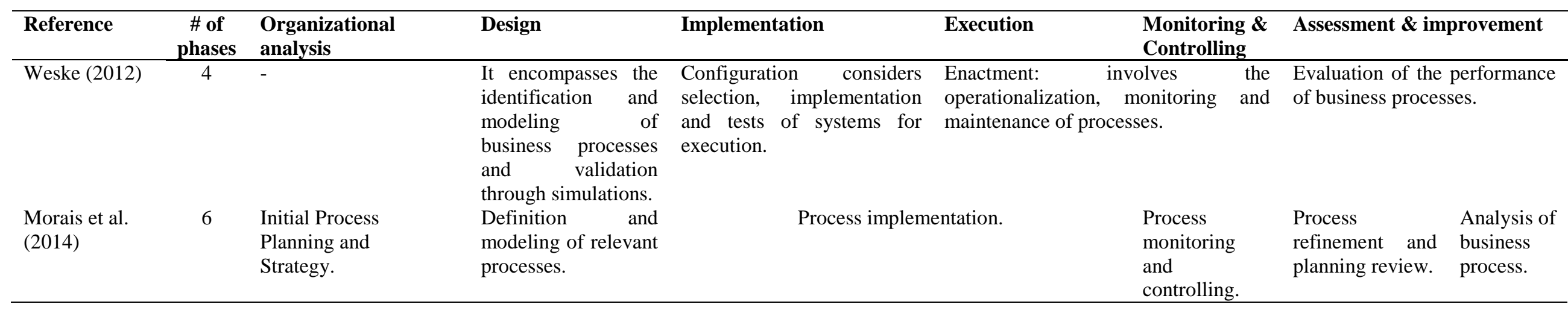




\subsection{1.}

Conceptual Framework for BPM development

Figure 3 presents the conceptual procedural framework with a life cycle approach for BPM development applied in this action research, as described further in Chapter 3. This framework is a blend of previous work offered in Table 4. However, the proposed framework in Figure 3 is more detailed than these previous works and aims to guide practitioners in similar undertakings. It includes the following phases: organizational analysis, design, implementation, execution and monitoring, assessment, as described next in this subsection. 
Figure 3 - The conceptual procedural framework for BPM development

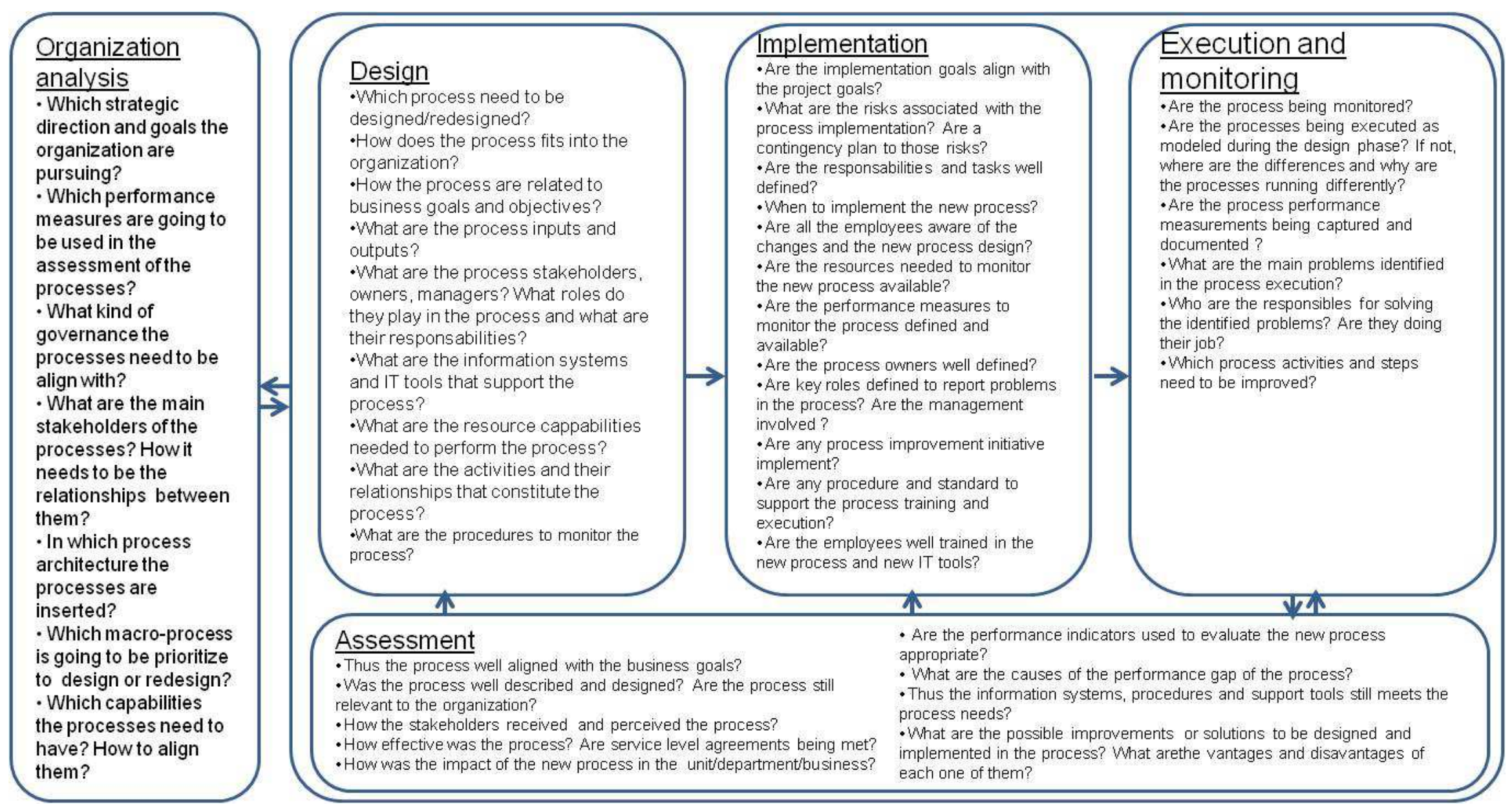

Source: Author. 


\subsubsection{1.}

\section{Organizational analysis}

The organizational analysis should on the one hand understand the enterprise by validating the strategic direction, determining stakeholders' relationships and consolidating strategic criteria. On the other hand, it should architect and align processes by identifying measures of performance, aligning process governance, prioritizing processes, aligning process capabilities and establishing enterprise transformation portfolio (Burlton, 2010). According to Jeston and Nelis (2006), the main inputs in this analysis are:

- Mission, vision, values, goals, strategic intent, objectives, implementation strategy;

- Corporate brochures, websites, annual report, to determine the image of the organization;

- Organization chart to assist in the identification of the main internal stakeholders;

- Product portfolio mix to determine the main products;

- List of key customer groups/types;

- Business model to determine main external partners;

- Documented and agreed process architecture;

Von Rosing et al. (2014) offer some typical questions that help in this analysis as: Which internal and external values and performance drivers exist and how they relate to the critical business factors? Which processes exist? What are the goals and/or purposes of the processes? What industries, functional areas, or organizations are involved with the processes? Who are the stakeholders, owners, and/or participants in the processes? Do the current processes present problems?

\subsubsection{2. Design}

The design phase aims to provide transparency of the current "as-is" process flow, to analyze the process flow, and to optimize it by creating a more efficient "to-be" process flow with higher quality. As part of the process analysis, 
organizational, structural, and technological weak points in the processes are revealed and improvement potential is identified. The results of the analysis, combined with corporate goals, are used to design the "to-be" processes. The actors involved in this phase are not only project leaders, BPM experts, and department managers, but also employees who are responsible for daily operations within the area (Scheer and Brabänder, 2010).

BPM projects aim to implement business change, whether that change is primarily organizational (improving business operating processes), technical (implementing or integrating software systems) or a combination of the two and business process design typically occurs as an early, critical phase rather than as an end in itself. In a process improvement project, the focus of the business process design phase is to streamline the process: to understand and measure the requirements, and to eliminate the risk of losing value through inefficient or inappropriate activities. In a technology implementation project, the focus is on understanding the processes that are being automated, and ensuring that the appropriate technology is selected, configured, and implemented to support them (von Rosing et al., 2014).

Jeston and Nelis (2006) offer a modeling guideline for the design phase based in the following items:

- Purpose and audience of the model: before modeling, it is important to specify the purpose and audience for that process model.

- Approval and governance: prior to modeling, it is important to specify who will approve and maintain the process models to avoid casualness from the responsibles during the project.

- The BIG picture: the first step in process modeling is to specify how the process fits into the overall processes of the organization, and then to drill down to the more detailed processes.

- Process model steps: the set of steps specifying how the process model is to be developed, reviewed, approved and maintained, and what the roles and responsibilities of the various people will be are outlined.

- Standards and reference models: ascertain the standards and reference models that are applicable. 
Similarly, von Rosing et al. (2014) offer the typical tasks of the design phase as follows:

- Define process content and the process maps, matrices, and models to be used

- Define relationships between process and business goals and objectives

- Identify and define business processes steps, and activities

- Identify and define stakeholders, process owners, managers, and roles

- Identify and define the required resources

- Develop and design process maps, matrices, and models

The "as-is" process design is motivated by the questions (Scheer and Brabänder, 2010): Who does what? In what sequence? What services or products are produced? What software systems and data are used to support the process?

\subsubsection{3. Implementation}

When processes have been modeled as "to-be" processes and the operational requirements are clearly understood, implementation through technology can commence (Scheer and Brabänder, 2010). In the implementation phase, all the designed and developed process improvements are 'brought to life' (Jeston and Neli, 2006). It involves multiple aspects from coordination with process owners, change management and process training (von Rosing et al, 2014). In other words, this phase focuses on the transformation of the daily process flow itself, the associated change in employee roles and responsibilities and last, but not least, on actual implementation of the IT systems (Scheer and Brabänder, 2010). In addition to IT-related implementation, communication and training concepts are also developed and executed to support employees affected by the new process and organizational changes. Process participants must be informed about the changes and take ownership of them. The implementation phase requires not only IT and process experts, but also people with good skills in internal communication and training in the context of change projects (Scheer and Brabänder, 2010). 
Jeston and Nelis (2006) offer a guideline for the implementation phase based in the following 13 steps:

1. Communications: involves true two-way communication with active participation of users.

2. Update implementation strategy: it is crucial when the implementation phase has been reached to complete a review of the original implementation strategy as the project team and the organization will have a much better understanding of the proposed changes and the implementation strategy has to take the current situation into account, and this probably will have changed since the initial determination of the implementation strategy.

3. Prepare for user acceptance testing: during this step the test cases for business testing are prepared. To this stage in the project the solution will have been tested against the written specifications of the business requirements. Now the solution must be tested for integration with the daily routine of the business users, as well as the implicit assumptions and expectations.

4. Training of the people who will be executing the processes. Just as the test scenarios can be developed based on the redesigned processes, the training materials can be created from the process documentation of the redesigned processes.

5. Complete business tests and pilots: where the user acceptance testing test cases are executed by the business, involving customers and suppliers, where appropriate. It should have a strong project management of the testing steps, a feedback mechanism easy to be used, and a mechanism to measure and share the results of the tests. It should be prepared to make changes 'on-the-fly' and feed these back into the deliverables (development) cycle.

6. Develop roll-out, back-out and contingency (project management skills)

7. Develop and run marketing programs 
8. Mentor staff: as mentioned previously in the training step, if selected people are trained as 'super users' first, they may then be used to train the remaining people and provide mentoring during the early period after going 'live'.

9. Roll-out changes: once the roll-out of the new processes has been implemented effectively, it must be ensured that the 'old' processes and supporting systems are no longer available to the staff. It is essential that a continuous improvement mechanism is put in place.

10. Monitor and adjust: during the roll-out of the changes, ample effort should be devoted to monitoring the progress of the roll-out and the progress towards achieving the business results.

\section{Provide feedback to users and stakeholders.}

Von Rosing et al. (2014) highlight the following typical tasks associated to the implementation phase: (i) set or revise goals, (ii) identify risks, (iii) distribute responsibilities and tasks, (iv) decide when to launch processes and tools, (v) plan training and mentoring, (vi) develop measurement metrics for a process performance model, (vii) enable process performance reporting and evaluation, (viii) identify, categorize, and label strategic, tactical, and operational process performance indicators, (ix) associate and categorize processes the strategic, Tactical, and Operational Process Performance Indicators to the relevant performance goals/objectives, $(x)$ create a performance model with decision making and reporting that illustrates the connection and relationship between Strategic, Tactical, and Operational Process Performance Indicators and the business goals and objectives, (xi) specify process ownership responsibility and tasks, (xii) select process owners, (xiii) implement a process-ownership organization, (xiv) appoint key process roles reporting or working with process owner, (xv) develop and implement process-improvement initiatives, (xvi) define the process and monitor process performance, (xvii) develop and manage policies and procedures related to the process, (xviii) ensure process adoption, harmonization, standardization, and integration, and (xix) enable process innovation and transformation (link to BPM Change Management and Continuous Improvement). 


\subsubsection{4. \\ Execution and monitoring}

The execution phase is the operationalization of the workflow definition (Netjes et al., 2006). Immediately after going live with the processes, it is important to establish an effective way of monitoring and governing the processes (von Rosing et al., 2014). Process monitoring is important to provide accurate information about the process instances (Weske, 2012). Herein, the measurement of the efficiency of the business processes implemented with the help of IT systems and the implementation of internal control systems to monitor compliance with the range of regulations are performed. The basic target here is to ensure the implemented business processes are running as they were defined during the design phase and that all monitoring steps are in place and working. Process efficiency is measured and analyzed against targets defined for the key performance indicators (KPIs) in order to identify opportunities to make changes. Continuous monitoring of business processes bridges the gap between corporate strategy and its operational implementation and nourish the measurement and control of business performance (Scheer and Brabänder, 2010). Von Rosing et al. (2014) highlight the following tasks in this phase: specify process measurements, select real-time process monitoring and governance, capture process performance measurements, and document performance measurement results for reporting and auditing.

\subsubsection{5.}

\section{Assessment}

As the execution and monitoring step is running, the process assessment phase takes place. Ohlsson et al. (2014) offer a process assessment heat map (PAHM) based on the following activities:

- Positioning: assesses the alignment of the process with the business strategy, objectives and values. This should address the following questions: How clearly has the management positioned the process role, mandate and importance in relation to the business strategy and operational model? Is the process well described in the management system? 
- Relating: assesses the attitudes, roles, risks and rewards of the stakeholders exposed to the process. This should address the following questions: Do stakeholders share risks and rewards among the units/departments? Do stakeholders have a clear understanding of the process? Are all the key stakeholders in agreement with the process interfaces and improvement roadmap?

- Preparing: assesses the availability and quality of key capabilities for improving the process. This should address the following questions: Do people have the right skills and competence? Are the necessary resources secured? Do we depend on a key person? Do people commit to the process?

- Implementing: assesses the performance of the process that is subject to analysis. This should address the following questions: What are customers' (internal, external) perceptions about the performance? How well do the interfaces work around supporting processes? How effective is the process?

- Proving: assesses the degree to which the process is appropriately monitored and measured. This should address the following questions: How well is the business impact measured? What is the right level of process evaluation/measuring? What are the relevant KPIs? What is the relevant feedback loop?

Von Rosing et al.(2014) highlight the following tasks in this phase: identify performance gap (link to BPM Governance), specify root cause of performance gap, identify alternatives and potential solutions, collect and list advantages and disadvantages of potential solutions, compare and align potential solutions to the existing process landscape, and evaluate and decide upon alternatives, if any are proposed.

Although there are no doubts in the literature about the growing relevance of BPM and the existence of different life cycle approaches, the understanding of how organizations should develop BPM, managing its change and evolution considering the entire life cycle and the identification of main critical factors and enablers for a successful BPM associated with each of the life cycle phases, so far 
received little attention from researchers. This research aims to address this gap with an action research. The next section presents the research design applied to achieve this aim. 


\section{3 \\ Research Design}

This current research is exploratory in nature and classified as an empirical and longitudinal study. The meaning for the term "empirical" is consistent to Flynn et al. (1990; p.251), which consists of the "knowledge based on real world observations or experiment", being also used in this paper "to describe field-based research which uses data gathered from naturally occurring situations or experiments". The longitudinal approach is aligned to a BPM evolution analysis with a life cycle approach in an organization, as it involves many aspects that take time to happen and to be understood such as process improvement initiatives, culture and human changes and organization learning (Jeston and Nelis, 2006; vom Brocke and Rosemann, 2010), all providing many rich lessons to enrich the academic literature and help practitioners in similar takings. Among the different research approaches found in literature for operations management, the action research is appropriate when the research is related to understanding the process of change, or its improvement to learn about it (Westbrook, 1995; Coughlan and Coghlan, 2002). The main aspects of an action research are as follows: it investigates more than actions; it is participatory; it occurs simultaneously with the action; and it is a sequence of events and approaches used to solve problems. Therefore, based on the research question, the state of the art in the field, and the characteristics of this empirical study, action research was the most appropriate method to be chosen. The conceptual procedural framework with a life cycle approach for BPM development offered in Figure 3 was the foundation of the research protocol used, as detailed next in this chapter.

\section{1.}

\section{Organization analysis}

The action research started with the organization analysis. In this part the activities performed belong to the group of "Projecting process" according to Paim et al. (2008) and aimed to identify and understand the organization's inner 
and outside environments, the Corporation's goal and strategy towards the architecture and alignment of the processes as indicated in (Jeston and Nelis, 2006; Zur Muehlen and Ho, 2006; ABPMP, 2009; Verma, 2009; Burlton, 2010; Houy et al., 2010; Morais et al., 2014; von Rosing et al., 2014). This phase prioritized the processes and defined the processes governance, the performance level to be expected, the needed capabilities (e.g., IT tools and human resources). Only the top management were actively involved in this early stage, but the employees from lower hierarchal levels were informed about the changes that the logistics areas was going through.

This phase counted with semi-structured interviews with the executives of the company involved with the logistics processes: the Supply Chain, Broadcasting Engineering, Scenography Production and the IT Directors. The interviews were conducted face-to-face using the questions displayed in the "Organization analysis" of the conceptual framework. The interviews duration varied from 2 to 4 hours each.

\section{2 . \\ Design}

The design phase was introduced next towards the understanding and streamlining of the prioritized process and the activities performed here were related to the group "Projecting process" according to Paim et al. (2008). Within this phase, the "as-is" processes were mapped, rethought from the perspective of the new software to be implemented within the logistics operations, and the "tobe" process was built aligned with the corporate goals and with roles and responsibilities well defined as indicated in (Netjes et al., 2006; Zur Muehlen and Ho, 2006; ABPMP, 2009; Scheer and Brabänder, 2010).

This phase counted with semi-structured interviews with the Logistics manager, the two coordinators of Materials and Broadcasting equipment and their four supervisors. The interviews were conducted face-to-face using the questions displayed in the conceptual framework for design. Interviews were also conducted with the others stakeholders of the processes (the Purchasing, Broadcasting Engineering, Scenography Production and IT Departments respectively represented by their management level) to define the main inputs and outputs of 
each process and the service-level agreement to be accomplished. The interviews duration varied from 2 to 4 hours each.

Another source of information was direct observation made in visits to the warehouses of the company where the execution of the processes could be observed and registered and the employees could also talk about the operational difficulties that were faced in the processes. Internal documents from the company were also used as secundary sources of information.

New processes were designed aided by the logistics local team and the IT team. In presential meetings, the processes were designed by the project team constituted by the warehouses supervisors, one of the logistics analysts, the corresponding coordinator responsible for the designed processes, with the constant support of an IT employee, external consultants and the technical representatives from the new software that were being implemented. All new processes designed were validated by the Logistics and the IT Managers.

\section{3. \\ Implementation}

The Implementation phase aimed to implement all the changes defined in the previous design phase and to prepare the execution phase according to (Zur Muehlen, 2006; Kannengiesser, 2008). An important procedure performed in this phase was training employees in the new processes' activities, flows and software, which required changes in employees' mindsets, roles and responsibilities as highlighted in (Jeston and Nelis, 2006; ABPMP, 2009; von Rosing, 2014). Software installation and set up the performance measurement system were also some of the activities performed in this phase as indicated in (ABPMP, 2009; Scheer and Brabänder, 2010).

Semi-structured interviews were conducted with the Logistics Manager, the coordinators of Materials and Broadcasting equipment and their supervisors to define based on the conceptual framework proposed the requirements to implement the processes. During the implementation phase, feedback from the supplier and the customers of the processes designed were gathered and the constant support from the IT employees was important to minor adjustments in 
the new IT tools and software. Regular meetings were stablished in the first weeks to follow the implementation.

A set of descriptive and illustrated manuals and standard procedures were created in this phase to support employees with material for the training routines. These documents were put close to the warehouses operations in easy access places also to provide support for doubts in the process implementation, as well as to serve as a tool for new employees. Two quality tools were tought in seminars to the warehouses supervisors: the PDCA method (plan, do, check, act/adjust) and the cause-and-effect diagram (Ishikawa chart). These tools helped the supervisors in the next phases to identify the mismatches and problems in the processes, the possible causes and propose solutions and plan actions. The "day-to-day processes management" activities, as defined by Paim et al. (2008), were performed in this phase and were tasks that involved implementing the work and changes as they were defined in the previous phases (Jeston and Nelis, 2006).

The implementation of the designed processes occurred in two waves. In the first wave, the processes were implemented in the headquarter warehouses of the enterprise. Then, after their use and evaluation, the processes were redesigned, whenever necessary, and implemented in a second wave on the subsidiaries of the company in other states.

\section{4 . \\ Execution and monitoring}

The execution and monitoring phase aimed to put in practice the process activities as they were specified in the design phase and to monitor the process performance capturing the performance indicators and documenting the measurement results. The execution of the new processes and the use of the new IT technologies was closely supervised and controlled by the warehouses' supervisors and the two coordinators. The Logistics manager was informed immediately about all problems that occurred with the new tools implemented towards the direction of actions to be taken. The regularity of the meetings to follow the implementation became less frequent as soon as the number of problems started to reduce and the operation started to work smoothly during the execution of the processes. 
Monthly meetings happened with the attendance of the Logistics manager, the two coordinators, their supervisors and the Logistics analysts to monitor and analyze results based in the procedures of the conceptual framework proposed. The measurement of the performance of the processes was supported by a new performance measurement system.

The execution and monitoring of the designed processes occurred in two waves. First in the headquarters warehouses of the enterprise and after on the subsidiaries of the company in other states. The "day-to-day processes management" activities, as defined by Paim et al. (2008) and in according to (Netjes, 2006; Zur Muehlen and Ho, 2006; Kannengiesser, 2008; Hallerbach, 2008; ABPMP, 2009; Houy et al., 2010; Weske, 2012; von Rosing et al., 2014), were also performed in this phase with tasks that involve putting into practice the designed processes, the monitoring and controlling the processes execution and the performing of the short-term changes. Tasks of the called group "Promote evolution and learning" also happened such as recording of processes performance and learning about the recording process.

\section{5.}

\section{Assessment}

The assessment phase aimed to analyze the process performance, identify opportunities of improvements such as workflow bottlenecks and eventual critical points, evaluate the alignment of the process with the business goals and the attitudes and roles of the stakeholders, identify, collect, compare potential solutions and decide upon the alternatives proposed.

In this phase the adherence of the new designed processes to the operations reality was evaluated in regular meetings that happened with the attendance of the Supply Chain director, the Logistics manager and their coordinators. The learning process emerged from the understanding of the historical basis of performance and the relationship between promised performance and achieved with the new processes. The tasks performed in this stage were related to the group "Promote evolution and learning" defined by Paim et al. (2008), were aligned with Ohlsson et al. (2014) PAHM and in accordance with (van der Aalst et al., 2003; Netjes et al., 2006; Zur Muehlen and Ho, 2006; Kannengieser, 2008; ABPMP, 2009; 
Weske, 2012; Morais et al., 2014; von Rosing, 2014). This phase also occurred in already mentioned two waves. The first wave evaluated the processes implemented in the headquarters warehouses. This evaluation gave information to the design and implementation of the new processes on the subsidiaries warehouses. The second wave of assessment will still be performed in the subsidiaries (until the end of this dissertation this phase was not performed). 


\section{4 \\ Main findings and Results}

The Chapter presents what happened in the case and the results of the action research. It is organized according to the conceptual procedural framework with a life cycle approach for BPM development presented in Figure 3.

\section{1. \\ Organization analysis}

The studied company belongs to a multinational media organization that has as mission "to create, produce and exhibit quality contents that meet artistic, cultural, informational, educational and entertainment purposes and, further, contribute to the development of individuals and society". The company has its contents exhibited in more than 100 countries and is recognized by the high quality standard of its contents. Since its foundation in the sixties, the enterprise has its history based in pioneering and innovation.

The Logistics department is responsible to support the company operations, what includes broadcasts soap operas, newscasts, sports events footages in studios and in external sites. The mission of the Logistics department is "to ensure that the growing demand for logistics services in the recordings, events, scenography constructions and others are met, through operations planning, focusing on the assets control, reliability of information, speed and security of the transactions". The scope of the logistics activities comprises warehousing, inventory management and transportation within the company's sites. Its organizational structure consists of one manager, two coordinators (one for each type of product), four supervisors to the warehouses, two logistics planners and nearly 100 employees. Its main stakeholders are the following departments: purchasing, scenography production, broadcasting engineering department and IT.

In the last years, the Logistics department has experienced an increase in its demands and was exposed to a network growth in a not standardized form. The 
logistics operations embraced new warehouses in a short period of time without redesigning the processes. Some of the warehouses did not even have specified processes while others have processes that were not adherent to the current reality.

The department manages seven warehouses distributed according to the type of product stored and point of consumption. The two main types of items to be stored are equipment and materials and there are warehouses to each of these types of items. The architecture in which the logistics processes are inserted are represented in Figure 4. The equipment leaves the warehouses to be used in scenography cities, studios and at external sites. After used, the equipment returns to the warehouse and remain available to be used in the next requesting recording. The materials are consumable items; therefore, after an item leaves the warehouse it does not return to be storage again. The materials are used in the construction of the scenography cities, scenarios of the recording studios and in all the recordings of the company. The materials warehouses have the usual inbound processes as receiving, put-away, replenishment, picking and shipping. To some items, like broadcasting equipment that have their own dedicated warehouses, the materials warehouse perform as a cross-docking point, delivering the items to another warehouse or to the user without storing them. Therefore, the logistics activities are different for this two kinds of products requiring different processes.

Figure 4 - Processes architecture

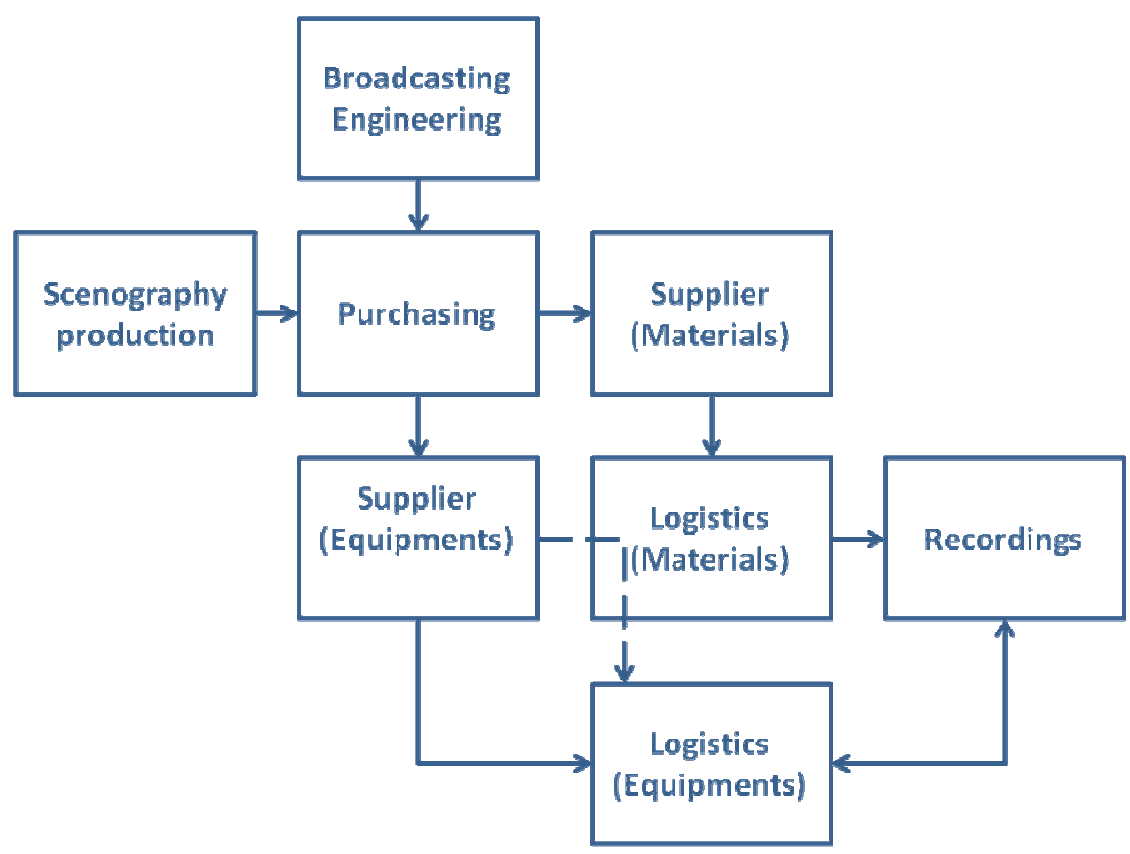

Source: Author. 
The performances of the processes are assessed aided by the following metrics: inventory accuracy, number of items without utilization for more than 12 months, total handling of items per employee, on-time delivery, storage capacity utilization. The performance measures are monitored by type of product (equipment/materials), type of activity (e.g., receiving, expedition and transfers) and by warehouse. These metrics give a general overview of the operations performance, but do not attend all the required controlling aspects needed to aid the management team to take better decisions. The main limitation is data generation and management, as the logistics processes were still to manual. This problem became more evident with the growth of the logistics demand associated to its scope increase within the company's operation. During this phase, the company executives mentioned the need for the new IT tools to better monitor and control the operations (materials and equipments) and to enable new performance metrics that could help in the decision making process. Then, that result in the acquisition of two new softwares, one specific to manage broadcasting equipment and other for materials (a warehouse management system - WMS). The new software to manage broadcasting equipment was chosen to be implemented first due the criticality of these products to the company's recordings and their monetary value.

Monthly meetings with the attendance of the processes stakeholders management level are settle to discuss the processes performance and responsibilities, to guarantee the collaborative coordination in process projects, to evaluate the fit between the processes and the company goals and the processes and IT projects and architecture. Annual meetings with the attendance of the Supply Chain director and the management level of the processes stakeholders are also settled to evaluate the processes performance and management and to discuss the next processes projects that could be performed. The annual meetings reevaluate the logistics processes priorities, to discuss and plan the future initiatives needed for the next years. The Supply Chain director with the Broadcasting Engineering, the Scenography Production, and the IT directors and the Logistics managers stablish the processes governance mechanism related to the logistics process. Every time there is an issue or a problem, first the supervisors of the departments involved try to reach a solution. If they fail, the 
departments' managers are involved in the issue. Only if extremely necessary the directors are involved to mediate the formed impasse between the departments and when needed made a final decision.

The organizational analysis phase ended with the consensus that the management of the logistics processes became an important issue to ensure the meeting of new and challenging demands, the alignment of the processes with new IT tools and the fulfillment of the strategic direction of the company. As a result, changes in the processes were required and trigged a BPM life cycle approach starting with the design of new processes, as seen next. Therefore, changes in the processes capabilities were discussed by the Supply Chain director and the Logistics manager. Warehouses' staffs were motivated to take additional habilitations aiming the increase the knowledge specialization of the logistics' employees. New employees would be hired and others redistributed along the operation. The implementation of new software to manage and control the operations in the warehouses would also require the adaptation of others systems of the company and in this the IT department was needed to be fully committed. Also with the implementation of these softwares new service agreements would be established with the processes customers and suppliers, requiring the involvement of the processes main stakeholders. As results of this phase, the company's strategy and goals were clearly understood, ensuring the right direction of the project and the requirements and mechanisms that form the bases for next BPM life cycle phases were built.

\section{2. \\ Design}

The organizational analysis revealed that the company desired more control and transparency about their stored items and the transactions performed in the enterprise's warehouses. Therefore, the logistics processes had to go through a new design phase aiming to align the processes to the company's strategy and the new reality of the logistics operation, reflecting the particularities of new activities, the logistics scope enlargement and the new IT systems acquired.

The definition of the processes goals and their alignment to the organizations goals, defined in the previous phase, was important to guide this 
phase and to the new processes and their monitoring procedures be successfully designed. In daily meetings, the design of the new processes was performed by the logistics team (coordinators, supervisors and analysts) and when more operational doubts occurred, the low hierarchical level operational staff was consulted. The processes customers and suppliers were also involved in the definition of the main inputs, outputs, service level required by the new logistics processes and the new roles and responsibilities of each part in the new processes, forming the implementation team. The SIPOC (Supplier, Input, Process, Output, Customer) tool was adopted to design the two macro-processes of the company (i.e., the logistics of equipment and the logistics of materials). Information from the evolved stakeholders was obtained and all the sub-processes of each kind of these macro-processes were detailed in the SIPOC. The tool helped and guided the design of the sub-processes performed by the logistics department. The SIPOC tool helped the team involved in the design of the new processes to view the processes at different levels. The lack of such a tool to support the processes visualization was a major issue faced in the company previously. The entire effort to design the equipment processes lasted 3 months and the design of the materials processes lasted 2 months.

The as-is sub-processes' mapping happened in-loco with the participation of the warehouses workers and then validated with the warehouses supervisors by checking with the former flowcharts existent in Excel. The flowcharts available were used to guide the beginning of the design efforts, but the use of a more modern software to this purpose became substantial. Then, the equipment processes were designed with the help of the Microsoft Visio software and the modeling tool used in the representation of the processes was the cross functional flowchart. To design the materials processes, the software used by the WMS consultancy was Bizagi, which uses a notation a little bit different from Visio and was the first barrier to the project, as Bizagi was not available previously in the company. As a result, the company employees needed to learn the main features of this new software to design the new processes and the IT department was responsible to provide the software. The mismatch between IT tools and modeling languages in the design phase was an issue considered by the company, as it can occur with negative consequences for the company. 
After the design of the cross-functional flowcharts, other tools used were the Classic and the Illustrated SOP's (Standard Operating Procedures). The documentation of the former processes was a big concern of the Logistics management. With SOP's the company aimed to standardize its processes, as well as to nurture the knowledge management of the Logistics department. The Classic SOP's described the standard activities of the processes that needed to be performed to main its quality level. The illustrated SOP's showed the standard steps in the IT systems that were necessary to be performed towards accomplishing a specific task of a process. The Illustrated SOP's were created from screen prints of the software and from their manuals.

The design of the processes was initiated by the processes dealing with equipment as the new software to control the transactions of these items was implemented first. Additional technologies were also implemented with the new software tools to improve the processes management, such as barcodes and radiofrequency identification (RFID) and were also considered in the new processes design. The constant support of IT department employees of the company and the technical representatives from the company of the new software were important to align the processes needs to the software settings and to indicate the points of divergence between the operations and the software capabilities.

With the new processes designed, changes in the logistics' human resources were identified resulting in changes in the warehouses' staff to be made in the next implementation phase by the warehouses supervisors, the logistics manager and their coordinators such as training in the new software, shifts adjustments, exchange of employees between warehouses and new hirings. As results of the phase, nineteen materials processes were designed in total, with seven different types of receiving, put-away, replenishment, the materials inventory, four types of transfers and six types of picking and shipping. Fourteen equipment processes were designed in total, with two types of discharge, four types of picking and shipping, three different types of receiving, the equipment transfer, the spare request, the equipment inventory, the equipment registration and the management of the equipment' kit. The differences were necessary to attend specificities of the operation. A better view of the processes was achieved with the use and support of design tools and they were designed aligned with the software settings and 
capabilities aiming to pursue the company's strategic objectives. The participation of the logistics employees and processes stakeholders made the new designed activities to be better accepted. The next implementation phase was a transition phase that aims to setting up and prepares all the aspects required to execute the new processes designed.

\section{3. Implementation}

With the new processes and their needed capabilities defined the processes implementation could begin. This phase aims to develop coordination between process owners and to perform change management and process training.

The Supply Chain director involvement and the active logistics manager participation were important to the interface with the IT department and in the coordination of the entire implementation phase, especially with the stakeholders from other departments establishing a collaborative enviroment. Moreover, in meetings with the logistics operational staff, the Logistics manager made clear the contribution of the logistics activities to support the company's goals and highlighted the importance of the new software implementation and the redesign of the processes. With the support from the IT employees, the Logistics analysts set up the needed procedures to feed the performance measures and monitor the processes.

Were part of the changes to be performed and managed the both new software implementation and the human resources aspects.

As broadcasting equipment are expensive items with a critical nature for the company's operation, the new software tool to control these items and their transactions was implemented first. Therefore, the processes regarding equipments were also the first ones to be implemented.

Some barriers happened during the new softwares implementation. The first one was delay in the new processes execution caused by the underestimated time to implement each of the new software. The installation and the testing phases for both the equipment software and the WMS took more time than expected. The next barrier was the lacking priority in the systems integration occurred in the problematic migration of the company in a new Enterprise Resource Planning 
(ERP) version (an upgrade) simultaneously with the implementation of the new software. Several problems of mismatches between the new software and the new version of the company ERP caused unexpected adaptations in the new processes, and the implementation of the full designed processes in prior was not possible. Another barrier emerged was the BPM team turnover with the change of the technical representatives from the WMS software in the middle of the project, what was stressful as the new people need to took some time to understand and be on the same level of knowledge about the project as the others technical representatives contributing to delay the new processes execution. These problems were consequence of the poor risks assessment, a lack of contingency plans and an improper project management.

The changes in the logistics' human resources identified in the previous design phase started to be performed. The shifts adjustments and exchange of employees between warehouses were responsibilities of the warehouses supervisors and the logistics coordinators, supervised by the logistics manager, who was also in charge of the required hirings.

Formal training sessions with the different people involved in the new processes were also performed. First, the logistics analysts and warehouses supervisors (called key users) were trained in the new software and IT tools purchased (barcode and RFID). The warehouses supervisors were also trained in quality tools of process analysis aiming to increase the process orientation and continuous improvement culture in the operations. All the employees from the logistics department were trained by the key users in the new processes with the use of the Classic and illustrated SOP's and oriented to resort to these documents in case of doubts, as processes users tend to better accept new processes with the use of instructions in self-help systems. These same employees were trained to use the new IT technologies. However, the ones involved in the equipment processes were trained for the use of the specific software for these processes, while the employees dealing with the material processes got training for the specific software for the material processes. The support and participation of the IT employees and the technical representatives from the new software guarantee that the complete knowledge about the new IT tools was absorbed by the logistics employees. 
The key users also guide the training of the main customers and suppliers of the processes in the new procedures, activities and software with the supervision of the logistics coordinators. Small adjustments in the new IT tools and processes were performed with the support of the IT team as result of the feedback provided by the processes' customers and suppliers and gathered by the Logistics department.

Meetings motivated by the Logistics manager with the management level of the others stakeholders clarify and highlight the objectives and purposes of the project and reinforce the importance of the process orientation and continous improvement culture.

In the second wave regarding the implementation of the processes in the subsidiaries, only the new software to control equipment was implemented. Then, only the new processes for equipment were implemented there. This was done with minor adjustments in the processes needed to the proper fit to incorporate the subsidiaries reality.

As results of this phase there were a clear understanding between employees and stakeholders of the changes in logistics activities, including the new IT tools, to support the company goals; their buy-in to the project with the new processes being better accepted by the users; the importance of a process view being communicated; the processes knowledge shared in the self-help system of learning built and the promotion of a routine of process analysis and continuous improvement. Next, the processes were ready to be executed, as described in the next subsection.

\section{4.}

\section{Execution and monitoring}

With the processes ready to go live the execution and monitoring phase started. The main goals of this phase are to run the processes as they were defined during the design phase and to perform the monitoring steps.

During the execution of the new processes, some issues and mismatches between operations needs and the software capabilities were identified and the lack of adequacy in the IT infrastructure emerge, such as a specific type of receveing done in the materials warehouses and not supported by the WMS and 
the lack of performance measurement metrics of the software to control the equipments operations. The involvement of the IT employees and the technical support of the software companies were important to find the appropriated solutions and then the new processes could run as expected.

Resistance from some employees inside the logistics department, as well as from other stakeholders, in perform the new processes was another barrier identified. These resistances were overcome by the Logistics manager efforts and the commitment of all the stakeholders to the project and to set a collaborative environment.

The monitoring procedure includes the processes performance measurement displayed in an Excel worksheet, mostly feed with information extracted from different information systems (e.g., ERP and WMS) and monthly meetings with the Logistics' manager, coordinators and warehouses supervisors to analyze the performance measures. The supervisors bring up the possible operational cause and effect relations of an identified problem and the logistics team discusses and agrees on the necessary actions to be taken to improve the processes performance. The highlights are sent to the Supply Chain Director. As more pressing priorities always happen in the execution phase, what capturs the attention of the logistics employees, the Logistics management was enrolled to encourage and to ensure that these meetings were realized frequently. The new software to control equipment and materials (WMS) impacted in the performance measurement system by allowing that new performance measures were implemented along the execution phase. The company also installed performance measurement boards in the warehouses and management offices that were updated with metrics values and latter included the addition of the new measures for a complete monitoring. These boards were designated to inform the employees about the activities performance, to raise awareness and affirm the importance of the performance measurement to a better process management.

In the subsidiaries of the company, the logistics performance measurement before the project was not performed. So based in the headquartes Performance Measurement System (PMS), in the second wave of the execution and monitoring phase in the subsidiaries, a set of performance measures was indicated to implement and the same procedures to follow the subsidiaries performance were indicated by researches. 
As results of the actions taken the resistance from employees and the mismatches between operations needs and softwares capabilities were overpassed; the importance of the performance measumerent was affirmed and the performing of the monitoring procedures guaranteed; the processes problems analysis and the logistics operations evaluation were perform by the own employees.

After one year performing and monitoring the new processes, the top management had sufficient information to realize the assessment phase.

\section{5.}

\section{Assessment}

The assessment phase aims to discuss and learn with the historical basis of the processes performance and to identify opportunities of improvements and possible solutions in the processes, planning future actions to be taken.

After one year executing and monitoring the new processes and despite the lack of adequacy in the IT infrastructure to perform the performance measurement, in top management meetings which happened with the attendance of the Supply Chain Director and the management level of the processes stakeholders, the Logistics manager reported the department's performance during the last year in more aggregate results and justified the measures / metrics that were bellow the target, proposing actions to be taken to improve the results. Together, the top management discussed if the aligment between the processes and business goals were being accomplish, the impacts of the new processes and their activities in the department and to the stakeholders, the relevance of the new processes and their performance indicators, the importance of the new information systems and tools to the processes performance, the successful changes and the improvements still needed. With the assessment of the new processes, some changes in the processes flowcharts were identified and proposed to be more coherent to the real activities performed and then the new processes and IT tools (software to control equipment, barcode and RFID) were considered to be implemented in the subsidiaries. The assessment of the new processes performance was performed with a proper evaluation in a more strategical level, and open space for planning future projects. The operations of the company's 
headquarter were the basis for the implementation of the BPM practices in the subsidiaries (second wave of the project).

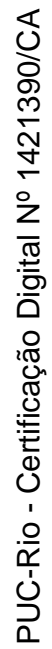




\section{5 \\ Discussions}

This chapter presents the discussions on the main research findings. The discussions are organized according to the main CSFs for the BPM development: strategic alignment, top management support, collaborative environment, user focus, employees training and empowerment, information technology, method and methodology, culture, performance measurement and project management. The main barriers faced by the company in its BPM development project are presented at the end of the chapter just before the research findings synthesis.

The BPM life cycle approach in the entertainment company studied started with the focus on the strategic alignment of the processes with the organization goals and the business strategy, what is aligned with the literature (Morais et al., 2014; Škrinjar and Trkman, 2013). The organization analysis phase ensured the complete understanding of the business context and paved the way to guarantee the adequate strategic alignment within the company. This alignment is one of the requirements to achieve long-term success and to improve processes performance in BPM projects and was present in all the BPM life cycles, as indicated in Bai and Sarkis (2013) and Škrinjar and Trkman (2013). The phases following the organization analysis (i.e., design, implementation, execution and monitoring and assessment) were accomplished according to the strategic priorities identified as indicated in Bandara et al. (2009). As a result, the different processes could present performance improvements such as an increase in assets and processes steps control, reliability of information, speed and security of the operations.

The top management support was also present in all of the life cycle phases. The top management executives involvement was important to establish the collaborative environment between the different processes stakeholders, to establish a trust feeling in the logistics employees about the changes required in the processes of the department and to support the strategic alignment, corroborating Crowe et al. (2002), Bandara et al. (2007; 2009), Ohtonen and Lainema (2011) and Škrinjar and Trkman (2013). The executives acted 
proactively participating in the regular meetings that happened in the different life cycle phases, motivating employees and stakeholders and setting up the need of a more process oriented view and the need of continuous improvement as a cultural value of the company, as suggested in the literature (i.e., Crowe et al., 2002; Bandara et al., 2009; Ohtonen and Lainema, 2011; Rohloff, 2009; Trkman, 2010; Škrinjar and Trkman, 2013). One should also mention the interaction and cooperation between the Logistics manager and the IT manager during all the phases of the life cycle, which allowed the alignment between the logistics needs and the IT specifications and was crucial for a better course of the activities, as stated in Žabjek et al. (2008), Bandara et al. (2009) and Ohtonen and Lainema (2011).

As mentioned, the top management involvement encouraged the collaborative environment among the logistics employees and the processes customers and suppliers, horizontally across their functional departments within the company, important factor highlighted in Crowe et al. (2002), Ohtonen and Lainema (2011) and Bai and Sarkis (2013). The processes' customers and suppliers were involved since the previous definitions of the processes requirements and provided feedback during the implementation and execution and monitoring phases, what helped to build the collaborative environment and contributed to the new processes acceptance, as indicated in Bandara et al. (2009) and Muellerleile et al. (2015). The involvement of the employees of the shop floor operation of the warehouses since the design phase elucidated doubts about specific characteristics of the warehouses operations allowing the operations specific and detailed knowledge to be shared. Their collaboration to the project and to the execution of the new tasks and activities designed contributed to the success of the changes implemented and to the culture of continuous improvement as a new reality to the logistics department, as indicated in Bandara et al. (2009) and Ohtonen and Lainema (2011).

These three firsts CSFs together guarantee the right strategic direction of the project, the needed focus in the requirements of each phase of the life cycle and maded the main barriers of the project to be surpassed.

Employees training and empowerment was also identified in the research as an important requisite for a BPM development success. With the major people changes happening in the implementation phase as indicated in (Jeston and Nelis, 
2006; Scheer and Brabänder, 2010), employees were driven to understand not only their individual activities, but also the entire processes in which they were involved and how the processes contributes to the organization's goals, what is highlighted in Škrinjar and Trkman (2013). Therefore, the Logistics manager attended meetings with the logistics operational staff to make clear the contribution of the logistics activities to support the company's goals, to reinforce the importance of their work to achieve these goals, and to highlight the needs for the new software implementation and the changes in the processes. The new software and the changes in the processes demanded specific trainings for the employees. These trainings are stressed in Trkman (2010) and Škrinjar and Trkman (2013) and aimed to guide the logistics employees in the new processes activities, procedures, roles and in the new IT tools, in the last case with a constant support of an IT employee and technical representatives from the new software companies as indicated in Bandara et al. (2009). Key-users were formed and guided the training of the processes customers and suppliers contributing to a better process acceptance by the stakeholders, what is stated in (Kumar et al., 2003; Ohtonen and Lainema, 2011; Muellerleile et al., 2015). The employees empowerment encouraged by the process analysis and evaluation by the own logistics employees is highlighted in Bandara et al. (2009) and Trkman (2010) who defendes the employees motivation in decision-making.

The method (or methodology) CSF includes all the procedures, tools and techniques used in the BPM life cycle and in accordance with the requirements of each of the life cycle phases. In the action research it was represented by: the process mapping tools used in the design phase to a proper processes visualizing, as indicated in Bandara et al. (2007) and Thompson et al. (2009), the self-help system of documents created to support the processes training of the implementation phase and the processes standardization, as stressed in Bandara et al. (2009), Rohloff (2009), Thompson et al. (2009) and Trkman (2010) and the increase of the processes acceptance, as highlight in Muellerleile et al. (2015), the quality tools to analyze and improve processes taught to the warehouse supervisors so they could use in the execution and monitoring phase and that reinforced the importance of the process orientation culture, as indicated in Bandara et al. (2009), Rohloff (2009), Thompson et al. (2009) and Trkman (2010), the meetings performed with the processes stakeholders to set up the 
processes requirements and with the logistics employees to clarify the importance of the project and the changes implemented during the life cycle, also stressed in Bandara et al. (2009), Rohloff (2009) and Trkman (2010), all these procedures, tools and techniques were part of the methodology to improve the processes. This is in accordance with Thompson et al. (2009) and with Rosemann and vom Brocke (2015) who state that the methods factor focuses on the needs of each of the process life cycle phases and in the integration of these methods with one another and with other management methods.

The user focus was another important critical success factor reveals in the action research. It represents the capacity of the BPM project to improve the user service efficiency and effectiveness of the processes (Bai and Sarkis, 2013). This factor could have been more positive to the project if was more present in the choice of the new softwares to be implemented. The processes users considered in the action research were the processes customers and suppliers. Their participation happened in all the BPM life cycle phases. In the design phase it occurred during the definition of the processes requirements and the service level agreements to be accomplished by the new processes. During the implementation phase, their feedback and perception about the changes implemented in the new processes were gathered and considered to guide improvements. The lack of an user focus in the choice of the new software to manage the processes contributed to the absence of adequate IT infrastructure (Smith and Fingar, 2003; de Bruin and Rosemann, 2007; Zur Muehlen and Ho, 2005; Valença et al., 2013), a barrier faced in the execution and monitoring phase (e.g., the specific type of receveing done in the materials warehouses and not supported by the WMS). In the assessment phase the processes' evaluation with a focus on the users' needs and the processes strategic goals was performed with an active involvement of the processes users, what proved to be essential for an successful assessment, corroborating Ngai et al. (2008), Bandara et al. (2009), Ravesteyn and Batenburg (2010) and Rosemann and vom Brocke (2015).

The culture factor was another CSF present in the project that help the company to be more process-centered, as indicated in Bai and Sarkis (2013). Corroborating Bandara et al. (2009), Thompson et al. (2009) Schmiedel et al. (2013) and Rosemann and vom Brocke (2015) the culture values and beliefs present in the life cycle phases (formalism in processes and business planning, 
collaboration, customer-orientation, excellence and responsibility) were essential to the project success and to the acceptance of the continuous improvement culture in the Logistics department despite the lack of propensity to change from some logistics employees and others processes users in the execution and monitoring phase. This resistance from employees and stakeholders to perform the changes implemented is a classic barrier indicated in Lee and Dale (1998), Grover (1999), de Bruin and Rosemann (2007) and Zur Muehlen and Ho (2005) in projects that involve changes and required an extra effort from the management level involved in the project to clarify to the resistant employees the importance of the changes implemented and the needed processes standardization.

The performance measurement was a factor influenced by the barriers caused by the IT factor and started to take shape in the organization analysis and design phases with the definition of the processes PMS (metrics and procedures) and the performance targets to be achieved. The use of performance boards displaying the processes performance metrics in the execution and monitoring phase ensured that the employees could adjust their behavior to be in line with the processes goals, as indicated in Rohloff (2009) and Škrinjar and Trkman (2013). Although there was a lack of IT support from the new software implemented to monitor and evaluate some aspects of the processes, this did not affect the performance measurement of the new processes. The logistics department used the ERP system to feed its PMS and the new measurements available in the new software, what resulted in a positive outcome from it as highlighted in Bandara et al. (2009). Then the assessment phase was performed without losing information, by confronting the processes goals and benchmarks with their real performances and sustaining the processes improvement as stressed in Bandara et al. (2009), Trkman (2010) and Bai and Sarkis (2013).

In the project the most problematic CSF showed to be Information Technology. With exception of the Organization Analysis phase, IT was a problematic CSF that caused issues and barriers in all the others phases of the life cycle. The lack of adequate IT infrastructure (Smith and Fingar, 2003; de Bruin and Rosemann, 2007; Zur Muehlen and Ho, 2005; Valença et al., 2013; Škrinjar and Trkman, 2013) was a barrier faced in the design, execution and monitoring, and assessment phases. The existent IT tools did not provide the proper support to specific activities such as process mapping, process performance monitoring and 
evaluation or they do not have the required capabilities or settings to match the processes needs. The lack of IT capabilities impacted in the performance of another CSF, the performance measurement, what is a frequent occurance as stressed in Bai and Sarkis (2013). The missing priority of systems integration (Zur Muehlen and Ho, 2005; Valença et al., 2013) was a barrier faced in the implementation phase. Together with the implementation of the new software occurred the problematic version migration of the company ERP, which ended delaying the new processes implementation. The distinct roles that IT should perform, such as a facilitator during the design phase and an implementer in the implementation phase in BPM projects were not played with enough success within the company, what is highlighted in Bandara et al. (2009) and Rosemann and vom Brocke (2015). The IT barriers were overcome by the collaborative environment set up and the constant involvement of the top management from the IT and Logistics departments as indicated in Bandara et al. (2009).

That shows how much IT matters to BPM projects even though the objective of this thesis is not to discuss the aspects related to BPM systems implementation. The logistics operations are not the core business of the company and were not seen as a priority to the IT department what cause many issues over the years. Despite the full support provided by the IT department of the company to the project, a better knowledge and planning about the IT tools that was going to be used and implemented in the project would avoid the future problems faced in the project corroborating the authors cited.

Together with the IT issues, the project management was also a problematic factor that contributed as a main barrier faced in the BPM development. The lack of an adequate IT infrastructure, as indicated in Smith and Fingar (2003), de Bruin and Rosemann (2007), Zur Muehlen and Ho (2005), Valença et al. (2013) and Škrinjar and Trkman (2013) in the design phase and the delay in the implementation of the modeled processes (Valença et al., 2013) in the implementation phase could be avoided with more information and a better planning and scheduling of the new IT software implementations, typical tasks of a proper project management, as suggested in Bandara et al. (2009) and Bai and Sarkis (2013). The BPM team turnover (Zur Muehlen and Ho, 2005; Valença et al., 2013) was also barrier that increased the new processes implementation delay and with proper risks identification of the project by the project management, a 
contingency plan could had been architected to deal with unexpected events like this, as indicated in Bandara et al. (2009).

Although there were many success factors revealed in the action research for the successful BPM development, some barriers were also identified in the different life cycle phases as mentioned in Chapter 4. Although the academic literature offers a huge list of barriers (please see Table 3), this action research identified just three main barriers with the others not representing major obstacles to the project. The barriers are the following:

- Poor knowledge of process-oriented approaches, aligned with Smith and Fingar (2003), Harmon (2004), Baker and Maddux (2005), de Bruin and Rosemann (2007) and Chong (2014);

- Lack of methodological rigor in execution of the project, aligned with de Bruin and Rosemann (2007) and Silva et al. (2012);

- Lack of BPM roles and responsibilities definition, aligned in Valença et al. (2013).

Although the company conducted the project without embracing a formal methodology for the BPM adoption and lacking formalism in defining BPM roles and in using processes management orientation approaches, the results were considered a success. These barriers were overcome by the combination the different critical success factors mentioned witin this section. Along the 2.5 years of this action research, the company learnt how to deal with those barriers and triumph in the implementation of the continuous improvement culture with a good acceptance of the Logistics department.

Table 5 provides a synthesis of the main barriers and critical success factors identified in the action research for each phase of the BPM life cycle, as well as the results obtained. 
Table 5 - Synthesis of the main barriers and critical success factors

\begin{tabular}{|c|c|c|c|c|c|}
\hline & Organization analysis & Design & Implementation & Execution and monitoring & Assessment \\
\hline $\begin{array}{c}\text { Missing or } \\
\text { Problematic } \\
\text { Critical } \\
\text { Success }\end{array}$ & & $\begin{array}{l}\text { - Information Technology } \\
\text { - Project management }\end{array}$ & $\begin{array}{l}\text { - Information Technology } \\
\text { - Project management }\end{array}$ & $\begin{array}{l}\text { - Information Technology } \\
\text { - User focus } \\
\text { - Culture }\end{array}$ & $\begin{array}{l}\text { - Information Technology } \\
\text { - Performance measurement }\end{array}$ \\
\hline Barriers & & $\begin{array}{l}\text { - Tecnology used isn't } \\
\text { compatible to processes design }\end{array}$ & $\begin{array}{l}\text { - Team members turnover } \\
\text { - Delay implementation of the new } \\
\text { processes } \\
\text { - Problems with systems } \\
\text { integration }\end{array}$ & $\begin{array}{l}\text { - Employees resistence in } \\
\text { perform the new activities } \\
\text { - IT tools don't present the } \\
\text { functionalities needed to monitor } \\
\text { all the processes steps } \\
\text { - Mismatches between processes } \\
\text { needs and IT tools }\end{array}$ & $\begin{array}{l}\text { - IT tools don't allow the } \\
\text { complete assessment of processes }\end{array}$ \\
\hline $\begin{array}{l}\text { Present } \\
\text { Critical } \\
\text { Success } \\
\text { Factors }\end{array}$ & $\begin{array}{l}\text { - Strategic alignment } \\
\text { - Top management support } \\
\text { - Collaborative enviroment } \\
\text { - User focus } \\
\text { - Methods and } \\
\text { methodology } \\
\text { - Culture }\end{array}$ & $\begin{array}{l}\text { - Strategic alignment } \\
\text { - Top management support } \\
\text { - User focus } \\
\text { - Collaborative enviroment } \\
\text { - Training of the employees } \\
\text { - Methods and methodology } \\
\text { - Culture }\end{array}$ & $\begin{array}{l}\text { - Strategic alignment } \\
\text { - Top management support } \\
\text { - Collaborative enviroment } \\
\text { - Training and empowerment of } \\
\text { the employees } \\
\text { - Methods and methodology } \\
\text { - Culture }\end{array}$ & $\begin{array}{l}\text { - Strategic alignment } \\
\text { - Top management support } \\
\text { - Collaborative enviroment } \\
\text { - Methods and methodology } \\
\text { - Project management } \\
\text { - Performance measurement }\end{array}$ & $\begin{array}{l}\text { - Strategic alignment } \\
\text { - Top management support } \\
\text { - User focus } \\
\text { - Project management } \\
\text { - Performance measurement } \\
\text { - Methods and methodology } \\
\text { - Culture }\end{array}$ \\
\hline Results & $\begin{array}{l}\text { - Allow the right } \\
\text { understanding of the } \\
\text { company and their strategy } \\
\text { and goals } \\
\text { - Set up the mechanisms } \\
\text { and requirements to perform } \\
\text { each of the project phases } \\
\text { - Guarantee the right } \\
\text { direction of the project }\end{array}$ & $\begin{array}{l}\text { - Alignment of the softwares } \\
\text { settings and capabilities with the } \\
\text { processes } \\
\text { - Better project acceptance from } \\
\text { the employees and stakeholders } \\
\text { - Process designed to pursue the } \\
\text { right objectives } \\
\text { - Better process visualizing } \\
\text { from the use of the support } \\
\text { design tools }\end{array}$ & $\begin{array}{l}\text { - Clear understanding of the } \\
\text { changes in logistics activities to } \\
\text { support the company goals by } \\
\text { employees and stakeholders } \\
\text { - Better process view } \\
\text { - Guarantee the buy-in of the } \\
\text { employees to the project } \\
\text { - Build a self-help system of } \\
\text { learning with knowledge shared } \\
\text { about the processes } \\
\text { - Better acceptance of the new } \\
\text { processes by the users } \\
\text { - Better understanding about the } \\
\text { new IT tools implemented and } \\
\text { changes implemented } \\
\text { - Promotion of a routine of process } \\
\text { analysis and continuous } \\
\text { improvement }\end{array}$ & $\begin{array}{l}\text { - Guarantee the performing of the } \\
\text { monitoring procedures } \\
\text { - Raise awareness and affirm the } \\
\text { importance of the performance } \\
\text { measumerent } \\
\text { - Analysis of the processes } \\
\text { problems and evaluation of the } \\
\text { logistics operations by the own } \\
\text { employees } \\
\text { - Mismatches between operations } \\
\text { needs and the softwares } \\
\text { capabilities were passed } \\
\text { - Resistance from employees } \\
\text { were passed }\end{array}$ & $\begin{array}{l}\text { - A proper evaluation by a more } \\
\text { strategical level the performance } \\
\text { of the logistics operations } \\
\text { - Planning of future projects }\end{array}$ \\
\hline
\end{tabular}




\section{6 Conclusions}

This thesis addresses a literature gap in BPM research through an empirical study that embraces, within a life cycle approach, the aspects on how organizations develop BPM tasks, and identifies critical factors and barriers faced in BPM and enablers needed to surpass these barriers. This addresses suggestions for future research in different works in the literature (e.g., Paim et al., 2008; Silva et al., 2012; Škrinjar and Trkman, 2013; Singer, 2015; Buh et al., 2015; Recker and Mendling, 2016) and aims to answer the two research questions proposed herein this thesis.

RQ1 - How should organizations develop BPM from a life cycle approach?

RQ2 - What are the main critical factors and enablers for a successful BPM and how do they act in each phase of the BPM life cycle?

The adoption of an action research method was relevant for both BPM research and Logistics research, as identify in Houy et al. (2010) and KaratasCetin and Denktas-Sakar (2013), as it allowed the observation, action in practice and learning during the project evolution along 2.5 years.

The research embraced the analysis of different life cycles models for BPM. Although there are many similarities, the presence of a phase of planning and analysis before an actual process design is not a consensus among them. The findings of this research confirms the importance of the inclusion of such a phase as it guarantees a proper organization analysis of the business goals and a strategic direction that guides the BPM project and sets the objectives to be pursued by the processes. Based on the activities and tasks to be performed contained in the BPM life cycle phases of the different models, a conceptual procedural framework emerged incorporating particularities of the company analyzed towards guiding the development of its logistics process management. The proposed framework includes five phases (i.e., organizational analysis, design, implementation, execution and monitoring, and assessment) and addresses the two before 
mentioned research questions. The framework is more detailed than the previous ones available in the literature and aims to guide practitioners in similar undertakings. However, certainly, as foreseen in other conceptual procedural frameworks offered in the literature, the development of BPM based on the proposed framework should be refined by more empirical studies (i.e., action researches, case studies, and surveys) opening avenues for future researches. The investigation of what happens in the transition between the BPM's life cycle phases, how those interactions happen and what are the critical success factors needed in those transitions where not contemplated within this master thesis and could be addressed in future researches to provide and nurture a complete knowledge in literature about theses aspects of BPM development.

The presence or lack of critical factors to BPM development in the studied company represented and created barriers to the project as well as enabled the project's success, corroborating Bandara et al. (2009) and Santos et al. (2015). The most challenging CSFs were the IT and the project management factors, which many times resulted in barriers that influenced significantly the project along different phases of the BPM life cycle. The IT factor was a problem in each of the life cycle phases (with exception of the Organization Analysis) and even though this thesis objective was not specifically to study the aspects related to the implementation of BPM systems, IT revealed to be one of the most important aspects in a BPM development project. When well planned and integrated to the project, IT worked as an enabler, but mostly in this study it was a main barrier, even though there was an existing effort from the IT department to participate actively in the project. A better integration between the IT department and the Logistics department would have avoided many of the barriers faced. The project management failed in the identification of risks in the project and did not create contingency plans to overcome unexpected events. The CSFs that worked as main enablers to surpass the different barriers in the project were top management support, collaborative environment among stakeholders and strategic alignment, what guaranteed the right focus in the different phases in the BPM life cycle and were essential to achieve the action research goals.

Despite the need highlighted in the literature to stablish a formal BPM structure, and the awareness of this fact within the company's management board, 
the current project was conducted without a formal methodology for the BPM adoption, lacking formalism in defining BPM roles and a lack in using processes management orientation approaches. However, this created addition barriers to the BPM development, they were not impeditive to the project's success. The company faced different barriers over the 2.5 years of the action research, but the combination of the CSFs presented during the project enabled the barriers to be surpassed.

One last final remark regards to the dynamism of the organizational environment, what results in the continuously need for updating the BPM development of a company. The assessment phase can point to needs for adjustments and changes within the processes, what can result in a new design phase, starting a new life cycle evolution. This BPM life cycle review effort never ends, reinforcing the need for the life cycle approach as the one conducted within this thesis. 


\section{References}

ANTONUCCI, Y.L.; GOEKE, R.J. Identification of appropriate responsibilities and positions for business process management success: Seeking a valid and reliable framework. Business Process Management Journal, v. 17, n. 1, p. 127146, 2011.

ARIYACHANDRA, T.R.; FROLICK, M.N. Critical success factors in business performance management - Striving for success. Information Systems Management, v. 25, n. 2, p. 113-120, 2008.

ASSOCIATION OF BUSINESS PROCESS MANAGEMENT PROFESSIONALS (ABPMP). Guia para Gerenciamento de Processos de Negócio - Corpo Comum de Conhecimento. São Paulo: ABPMP, 2009. Versão 2.0 .

BAI, C.; SARKIS, J. A grey-based DEMATEL model for evaluating business process management critical success factors. International Journal of Production Economics, v. 146, n. 1, p. 281-292, 2013.

BAKER, G.; MADDUX, H. Enhancing organizational performance: facilitating the critical transition to a process view of management. SAM Advanced Management Journal, v. 70, n. 4, p. 43, 2005.

BANDARA, W.; ALIBABAEI, A.; AGHDASI, M. Means of achieving business process management success factors. In: Proceedings of the 4th Mediterranean Conference on Information Systems. Department of Management Science and Technology, Athens University of Economics and Business, 2009.

BANDARA, W.; INDULSKA, M.; CHONG, S.; SADIQ, S. Major issues in business process management: an expert perspective. In: The European Conference on Information Systems, 15, St Gallen, Switzerland. 2007.

BITKOWSKA, A. The Orientation of Business Process Management toward the Creation of Knowledge in Enterprises. Human Factors and Ergonomics in Manufacturing \& Service Industries, v. 25, n. 1, p. 43-57, 2015.

BUH, B.; KOVAČIČ, A.; INDIHAR ŠTEMBERGER, M. Critical success factors for different stages of business process management adoption-a case study. Economic Research-Ekonomska Istraživanja, v. 28, n. 1, p. 243-258, 2015 .

BULANDER, R.; DIETEL, M. The consideration of organizational, human and corporate cultural factors in the implementation of business process management 
projects: Social factors to prevent failure of BPM projects. In: e-Business (ICEB), 2013 International Conference on. IEEE, 2013. p. 1-9.

BURLTON, R. Delivering business strategy through process management. In: vom Brocke, J., Rosemann, M. (Eds) Handbook on Business Process Management 2. Springer Berlin Heidelberg, 2010. p. 5-37.

CAMPOS, V.F. Gerenciamento pelas diretrizes (hoshin Kanri). Universidade Federal de Minas Gerais, 1996.

CHONG, S. Business process management for SMEs: an exploratory study of implementation factors for the Australian wine industry. Journal of Information Systems and Small Business, v. 1, n. 1-2, p. 41-58, 2014.

COUGHLAN, P.; COGHLAN, D. Action research for operations management. International Journal of Operations and Production Management, v. 22, n. 2, p. 220-240, 2002.

CROWE, T.J.; FONG, P.M.; BAUMAN, T.A.; ZAYAS-CASTRO J.L. Quantitative risk level estimation of business process reengineering efforts. Business Process Management Journal, v. 8, n. 5, p. 490-511, 2002.

DAVENPORT, T.H. Process innovation: reengineering work through information technology. Boston: Harvard Business Press, 2013. 352 p.

DE BOER, F.G.; MÜLLER, C.J.; TEN CATEN, C.S. Assessment model for organizational business process maturity with a focus on BPM governance practices. Business Process Management Journal, v. 21, n. 4, p. 908-927, 2015.

DE BRUIN, T.; DOEBELI, G. An organizational approach to BPM: the experience of an Australian transport provider. In: vom Brocke, J., Rosemann, M. (Eds). Handbook on Business Process Management 2. Springer Berlin Heidelberg, 2010. p. 559-577.

DE BRUIN, T.; ROSEMANN, M. Using the Delphi technique to identify BPM capability areas. In: ACIS 2007 Proceedings, 18, 2007, Toowoomba, p. 42.

DEMING, W. E. Qualidade: a revolução da administração. Rio de Janeiro: Marques Saraiva, 1990. 367 p.

DE OCA, I.M.M; SNOECK, M.; REIJERS, H.A.; RODRIGUEZ-MORFFI, A. A systematic literature review of studies on business process modeling quality. Information and Software Technology, v. 58, p. 187-205, 2015.

ELZINGA, D.J.; HORACK, T.; LEE, C.Y.; BRUNER, C. Business process management: survey and methodology. IEEE Transactions on Engineering Management, v. 42, n. 2, p. 119-128, 1995. 
FLYNN, B.B.; KAKIBARA, S.S.; SCHROEDER, R.G.; BATES, K.A.; FLYNN, E.J. Empirical research methods in operations management. Journal of Operations Management, v. 9, n. 2, p. 250-284, 1990.

GALBRAITH, J.R. Designing the global corporation. Jossey-Bass, 2000.

GARAVAN, T.N. Training, development, education and learning: different or the same?. Journal of European Industrial Training, v. 21, n. 2, p. 39-50, 1997.

GOLDRATT, E.M. Theory of constraints. Croton-on-Hudson: North River, 1990.

GROVER, V. From business reengineering to business process change management: a longitudinal study of trends and practices. IEEE Transactions on Engineering Management, v. 46, n. 1, p. 36-46, 1999.

GROVER, V.; KETTINGER, W.J. Process think: winning perspectives for business change in the information age. IGI Global, 2000. 399 p.

GRUDZEWSKI, W. M.; HEJDUK, I. Enterprise of the future: Strategic vision. Warsaw: DIFIN, 2002.

GUPTA, P. Beyond PDCA-A new process management model. Quality Progress, v. 39, n. 7, p. 45, 2006.

HALLERBACH, A.; BAUER, T.; REICHERT, M. Managing Process Variants in the Process Lifecycle. In: 10th Int'l Conf. on Enterprise Information Systems (ICEIS' 08), 2008, Barcelona, Spain.

HARMON, P. Evaluating an organization's business process maturity. Business Process Trends, v. 2, n. 3, p. 1-11, 2004.

HARMON, P. The scope and evolution of business process management. In: vom Brocke, J., Rosemann, M. (Eds). Handbook on Business Process Management 1. Springer Berlin Heidelberg, 2010. p. 37-81.

HARMON, P. Business process change (3rd Ed). Whaltam: Morgan Kaufmann, 2014. 520 p.

HARRINGTON, J. Aperfeiçoando processos empresariais: estratégia revolucionária para o aperfeiçoamento da qualidade, da produtividade e da competitividade. São Paulo: MakronBooks, 1993.

HAYASHI, N.; HERMAN, G. A coordination-theory approach to exploring process alternatives for designing differentiated products. Social Science Research Network, MIT Sloan School Working Paper, no. 4362-02. 2002.

HLUPIC, V. Knowledge and business process management. IGI Global, 2002. $308 \mathrm{p}$. 
HOUY, C.; FETTKE, P.; LOOS, P. Empirical Research in Business Process Management-Analysis of an emerging field of research. Business Process Management Journal, v. 16, n. 4, p. 619-661, 2010.

IMI. Business Processes - an IMI Briefing's, Innovative Manufacturing Initiative, 1994.

JESTON, J.; NELIS, J. Business process management. Butterworth-Heinemann, 2006.

KANNENGIESSER, U. Subsuming the BPM life cycle in an ontological framework of designing. In: Advances in Enterprise Engineering I. Springer Berlin Heidelberg, 2008. p. 31-45.

KAPLAN, R.S.; NORTON, D.P. The balanced scorecard: translating strategy into action. Boston: Harvard Business Press, 1996. 322 p.

KAPLAN, R.S.; NORTON, D.P. Alignment: Using the balanced scorecard to create corporate synergies. Boston: Harvard Business Press, 2006. 302 p.

KARATAS-CETIN, C.; DENKTAS-SAKAR, G. Logistics Research beyond 2000: Theory, Method and Relevance. The Asian Journal of Shipping and Logistics, v. 29, n. 2, p. 125-144, 2013.

KO, R.K.L.; LEE, S.S.G.; WAH LEE, E. Business process management (BPM) standards: a survey. Business Process Management Journal, v. 15, n. 5, p. $744-$ 791, 2009.

KUMAR, V.; MAHESHWARI, B.; KUMAR, U. An investigation of critical management issues in ERP implementation: emperical evidence from Canadian organizations. Technovation, v. 23, n. 10, p. 793-807, 2003.

LAUTENBACHER, F.; BAUER, B.; SEITZ, C. Semantic Business Process Modeling-Benefits and Capability. In: AAAI Spring Symposium: AI Meets Business Rules and Process Management, California, 2008. p. 71-76.

LEE, R.G.; DALE, B.G. Business process management: a review and evaluation. Business Process Management Journal, v. 4, n. 3, p. 214-225, 1998.

MARKUS, M.L.; JACOBSON, D.D. Business process governance. In: vom Brocke, J., Rosemann, M. (Eds). Handbook on Business Process Management 2. Springer Berlin Heidelberg, 2010. p. 201-222.

MCCORMICK, K. Quality tools and techniques. In: MCCORMICK, K. Quality. Woburn: Butterworth-Heinemann. 2002. p 231-249.

MISSION, I.C. The Benefits of Implementing a Parent Standard Operations Procedure (SOP) that Defines the Dependencies Between Other SOPs and Ensures Product Traceability. In: SpaceOps 2008 Conference, 2008. 
MONTEVECHI, J.A.B; COSTA, R.F.S; MARINS, F.F.; LEAL, F.; JESUS, J.T.de. Combined use of modeling techniques for the development of the conceptual model in simulation projects. In: Simulation Conference, 2008. WSC 2008. Winter. IEEE, 2008. p. 987-995.

MORAIS, R.M.; KAZAN, S.; DE PADUA, S.I.D.; COSTA, A.L. An analysis of BPM lifecycles: from a literature review to a framework proposal. Business Process Management Journal, v. 20, n. 3, p. 412-432, 2014.

MUELLERLEILE, T.; RITTER, S.; ENGLISCH, L.; NISSEN, V.; JOENSSEN, D.W. The Influence of Process Acceptance on BPM: An Empirical Investigation. In: Business Informatics (CBI), 2015 IEEE 17th Conference on. IEEE, 2015. p. 125-132.

NETJES, M.; REIJERS, H.A.; VAN DER AALST, W.M.P. Supporting the BPM life cycle with FileNet. In: Proceedings of the CAiSE. 2006. p. 497-508.

NG, S.C.; RUNGTUSANATHAM, M.; ZHAO, X.; LEE, T.S. Examining process management via the lens of exploitation and exploration: Reconceptualization and scale development. International Journal of Production Economics, v. 163, p. $1-15,2015$.

NGAI, E.W.T.; LAW, C.C.H.; WAT, F.K.T. Examining the critical success factors in the adoption of enterprise resource planning. Computers in Industry, v. 59, n. 6, p. 548-564, 2008.

NONAKA, I. The knowledge-creating company. Boston: Harvard Business Review Press, 2008.

OHLSSON, J.; HAN, S.; JOHANNESSON, P.; RUSU, L. Developing a Method for Prioritizing Business Process Improvement Initiatives. In: PACIS. 2014. p. 342.

OHNO, T. Toyota production system: beyond large-scale production. Portland: CRC Press, 1988. 176 p.

OHTONEN, J.; LAINEMA, T. Critical success factors in business process management-A literature review. In: Proceedings of IRIS. 2011. p. 572-585.

PAIM, R.; MANSUR CAULLIRAUX, H.; CARDOSO, R. Process management tasks: a conceptual and practical view. Business Process Management Journal, v. 14, n. 5, p. 694-723, 2008.

PEREIRA, C.M.; SOUSA, P. A method to define an Enterprise Architecture using the Zachman Framework. In: Proceedings of the 2004 ACM Symposium on Applied Computing. ACM, 2004. p. 1366-1371.

POLYVYANYY, A.; SMIRNOV, S.; WESKE, M. Business process model abstraction. In: vom Brocke, J., Rosemann, M. (Eds). Handbook on Business Process Management 1. Springer Berlin Heidelberg, 2015. p. 147-165. 
PORTER, M.E. Creating and sustaining superior performance. Competitive Advantage, p. 167, 1985.

RAHIMI, F.; MØLLER, C.; HVAM, L. Business process management and IT management: The missing integration. International Journal of Information Management, v. 36, n. 1, p. 142-154, 2016.

RAVESTEYN, P.; BATENBURG, R. Surveying the critical success factors of BPM-systems implementation. Business Process Management Journal, v. 16, n. 3, p. 492-507, 2010.

RECKER, J.; MENDLING, J. Recommendations from analyzing the state-of-theart of business process management research. In: EMISA Forum. Gesellschaft fuer Informatik, 2016. p. 16-21.

RINGIM, K.; RAZALLI, M.R.; HASNAN, N. Critical success factors for business process management for small and medium banks in Nigeria. Business and Management Review, v. 2, n. 1, p. 83-91, 2012.

ROHLOFF, M. Case study and maturity model for business process management implementation. In: DAYAL, U.; EDER, J.; KOEHLER, J.; REIJERS, H.A. (Eds). Business Process Management: 7th International Conference, BPM 2009, Ulm, Germany, September 8-10, 2009. Proceedings. Springer Berlin Heidelberg, 2009. p. 128-142.

ROSEMANN, M. The service portfolio of a BPM center of excellence. In: vom Brocke, J., Rosemann, M. (Eds). Handbook on Business Process Management 2. Springer Berlin Heidelberg, 2010. p. 267-284.

ROSEMANN, M.; VOM BROCKE, J. The six core elements of business process management. In: VOM BROCKE, J., ROSEMANN, M. (Eds). Handbook on Business Process Management 1. Springer Berlin Heidelberg, 2015. p. 105-122

RUMMLER, G.A.; BRACHE, A.P. Improving performance: How to manage the white space on the organization chart. San Francisco: John Wiley \& Sons, 2012. $270 \mathrm{p}$.

SANTOS, H.R.M.; VALENÇA, G.A.; ALVES, C.F. Strategies for Managing Critical Success Factors of BPM Initiatives in Brazilian Public Organizations: A Qualitative Empirical Study.iSys-Revista Brasileira de Sistemas de Informação, v. 8, n. 1, p. 42-64, 2015.

SCHEER, A.W.; BRABÄNDER, E. The process of business process management. In: vom Brocke, J., Rosemann, M. (Eds). Handbook on Business Process Management 2. Springer Berlin Heidelberg, 2010. p. 239-265.

SCHEER, A.W.; NÜTTGENS, M. ARIS architecture and reference models for business process management. In: VAN DER AALST, W.; DESEL, J.; 
OBERWEIS, A. (Eds). Business Process Management: Models, Techniques, and Empirical Studies. Springer Berlin Heidelberg, 2000. p. 376-389.

SCHEIN, E.H. Organizational culture and leadership. San Francisco: John Wiley \& Sons, 2006.

SCHMIEDEL, T.; VOM BROCKE, J.; RECKER, J. Which cultural values matter to business process management? Results from a global Delphi study. Business Process Management Journal, v. 19, n. 2, p. 292-317, 2013.

SHINGO, S. A study of the Toyota production system: From an Industrial Engineering Viewpoint. Portland: CRC Press, 1989. 296 p.

SILVA, L.A.da; DAMIAN, I.P.M.; DE PÁDUA, S.I.D. Process management tasks and barriers: functional to processes approach. Business Process Management Journal, v. 18, n. 5, p. 762-776, 2012.

SINGER, R. Business process management in small-and medium-sized enterprises: an empirical study. In: Proceedings of the 7th International Conference on Subject-Oriented Business Process Management. ACM, 2015. p. 9.

ŠKRINJAR, R.; TRKMAN, P. Increasing process orientation with business process management: Critical practices'. International Journal of Information Management, v. 33, n. 1, p. 48-60, 2013.

SMITH, H.; FINGAR, P. IT Doesn't Matter-Business Processes Do. Tampa: Meghan-Kiffer Press, 2003.

SPANYI, A. Business process management governance. In: vom Brocke, J., Rosemann, M. (Eds). Handbook on Business Process Management 2. Springer Berlin Heidelberg, 2010. p. 223-238.

TALWAR, R. Business re-engineering-A strategy-driven approach. Long Range Planning, v. 26, n. 6, p. 22-40, 1993.

THOMPSON, G.; SEYMOUR, L.F.; O’DONOVAN, B. Towards a BPM success model: An analysis in south african financial services organisations. In: HALPIN, T.; KROGSTIE, J.; NURCAN, S.; PROPER, E.; SCHMIDT, R.; SOFFER, P.; UKOR, R. (Eds). Enterprise, business-process and information systems modeling: 10th International Workshop, BPMDS 2009, and 14th International Conference, EMMSAD 2009, held at CAiSE 2009, Amsterdam, The Netherlands, June 8-9, 2009. Proceedings. Springer Berlin Heidelberg, 2009. p. 1-13.

TKA, M.; GHANNOUCHI, S.A. Comparison of Business Process Models as Part of BPR Projects. Procedia Technology, v. 5, p. 427-436, 2012.

TRKMAN, P. The critical success factors of business process management. International Journal of Information Management, v. 30, n. 2, p. 125-134, 2010. 
VALENCA, G.; ALVES, C.F.; SANTANA, A.F.L.; OLIVEIRA, J.A.P; SANTOS, H.R.M. Understanding The Adoption Of BPM Governance In Brazilian Public Sector. In: ECIS. 2013. p. 56.

VAN DER AALST, W.M.P.; TER HOFSTEDE, A.H.M.; WESKE, M. Business process management: A survey. In: VAN DER AALST, W.M.P.; WESKE, M. (Eds). Business Process Management: International Conference, BPM 2003 Eindhoven, The Netherlands, June 26-27, 2003 Proceedings. Springer Berlin Heidelberg, 2003. p. 1-12.

VERMA, N. Business process management: profiting from process. New Delhi: Global India Publications, 2009. 311 p.

VOM BROCKE, J.; ROSEMANN, M. Handbook on business process management. Heidelberg: Springer, 2010.

VOM BROCKE, J.; SINNL, T. Culture in business process management: a literature review. Business Process Management Journal, v. 17, n. 2, p. 357378, 2011.

VON ROSING, M.; VON SCHEEL, H.; SCHEER, A.W. The complete business process handbook: body of knowledge from process modeling to BPM. Whaltam: Morgan Kaufmann, 2014. 776 p.

WESKE, M. Business process management: concepts, languages, architectures. Springer Science and Business Media, 2012. 368 p.

WESTBROOK, R. Action research: a new paradigm for research in production and operations management. International Journal of Operations and Production Management, v. 15, n. 12, p. 6-20, 1995.

WILLAERT, P.; VAN DEN BERGH, J.; WILLEMS, J.; DESCHOOLMEESTER, D. The process-oriented organisation: a holistic view developing a framework for business process orientation maturity. In: ALONSO, G.; DADAM, P.; ROSEMANN, M. (Eds). International Conference on Business Process Management: 5th International Conference, BPM 2007, Brisbane, Australia, September 24-28, 2007. Proceedings. Springer Berlin Heidelberg, 2007. p. 1-15.

ŽABJEK, D.; KOVAČIĆ, A.; INDIHAR ŠTEMBERGER, M. Business process management as an important factor for a successful ERP system implementation. Ekonomska Istraživanja, v. 21, n. 4, p. 1-18, 2008.

ZAIRI, M.; SINCLAIR, D. Business process re-engineering and process management: a survey of current practice and future trends in integrated management. Management decision, v. 33, n. 3, p. 3-16, 1995.

ZUR MUEHLEN, M.; HO, D.T.Y. Risk management in the BPM lifecycle. In: BUSSLER, C.J.; HALLER, A. (Eds). Business Process Management Workshops: BPM 2005 International Workshops, BPI, BPD, ENEI, BPRM, 
WSCOBPM, BPS, Nancy, France, September 5, 2005. Revised Selected Papers. Springer Berlin Heidelberg, 2005. p. 454-466. 


\section{Appendix I: BPM life cycle models}

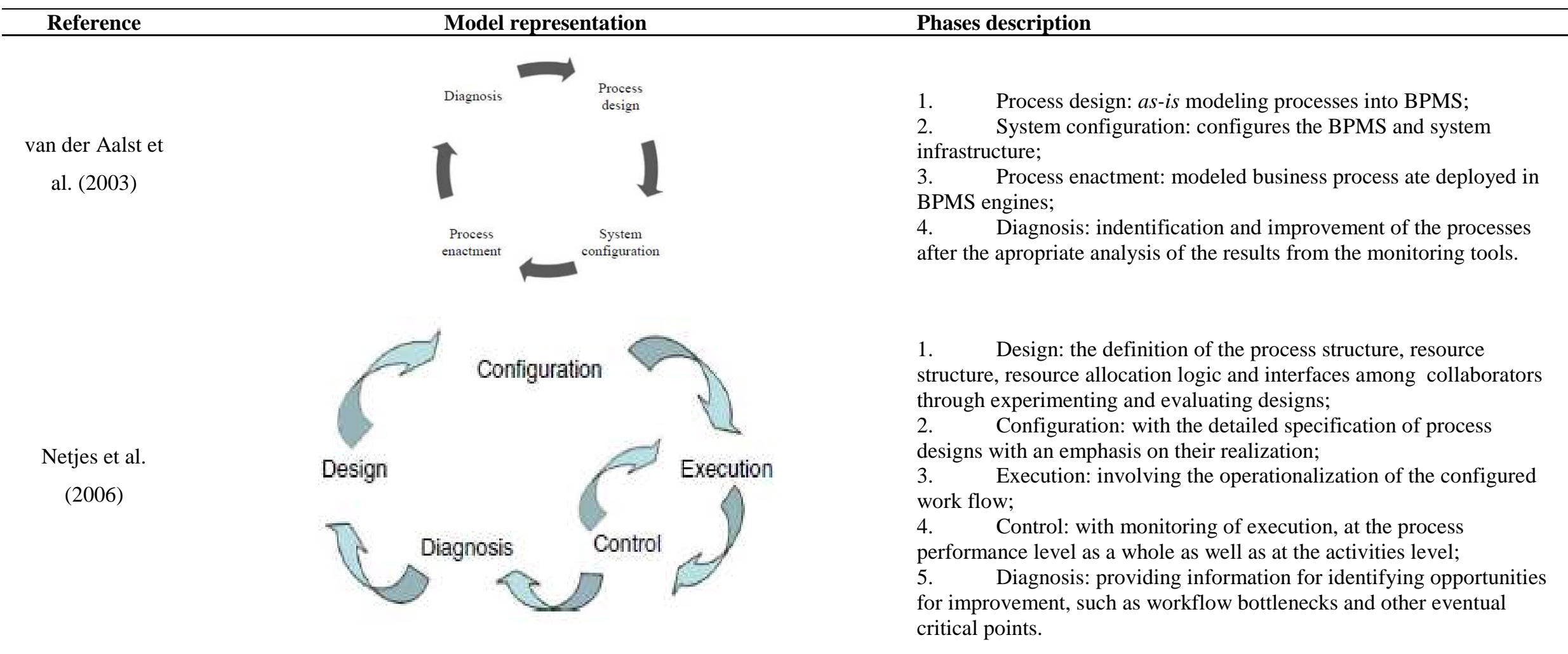




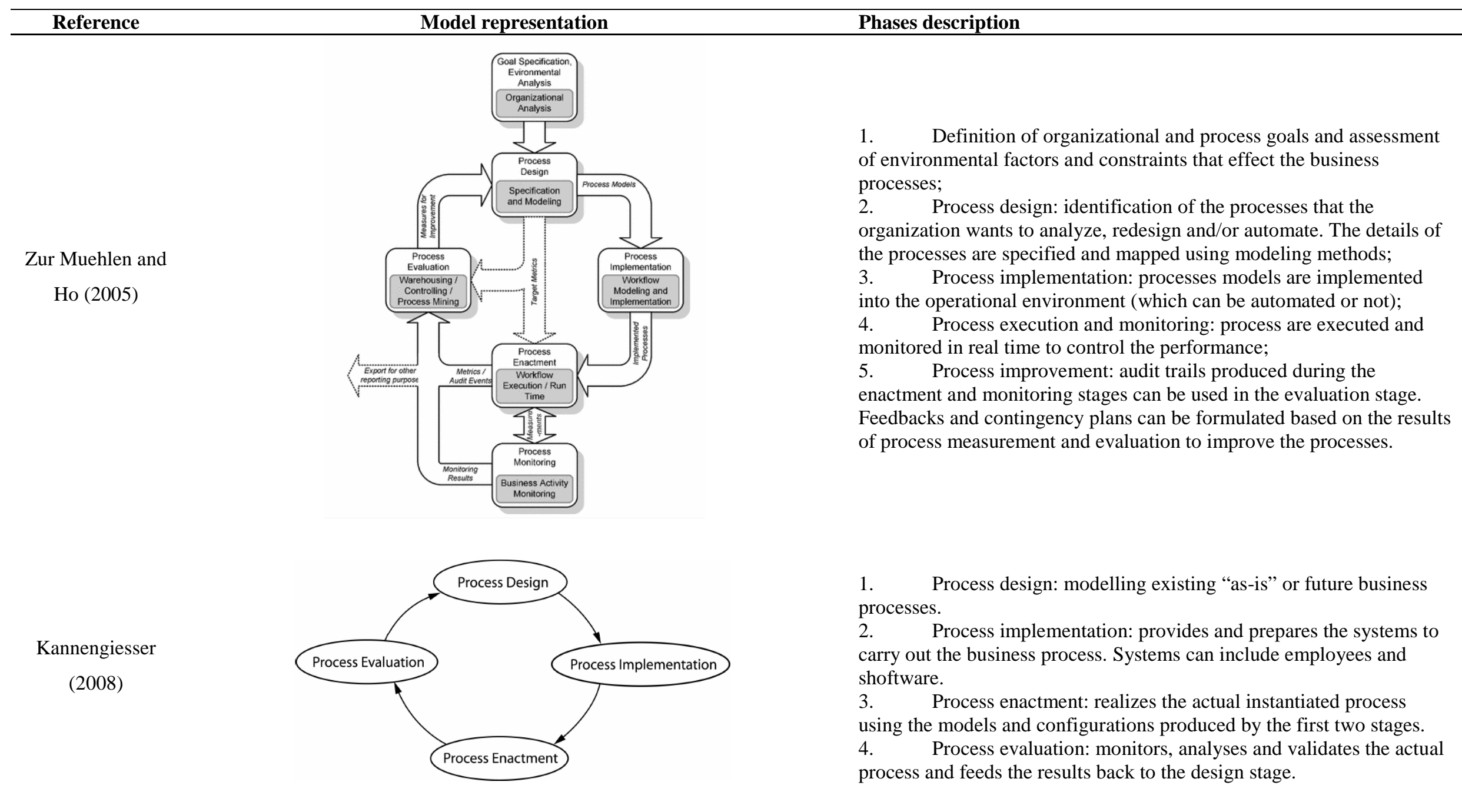




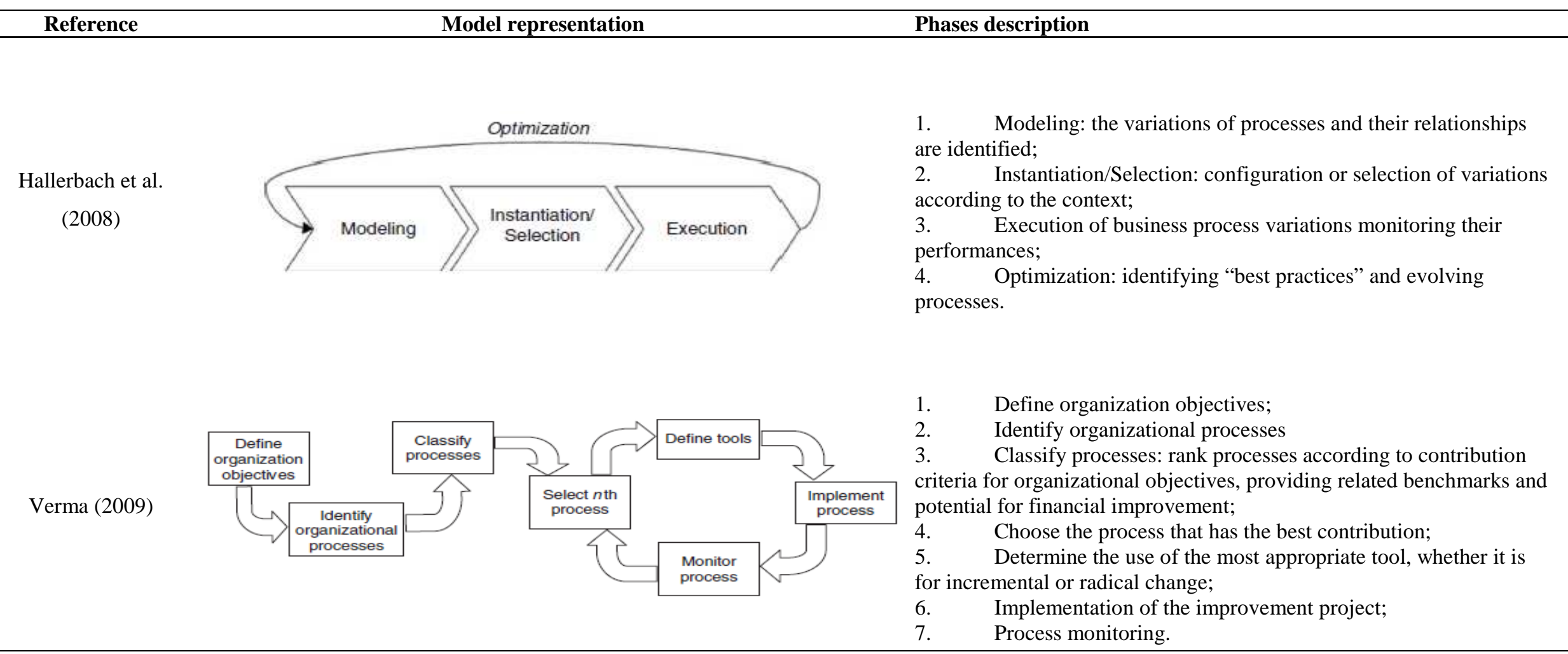




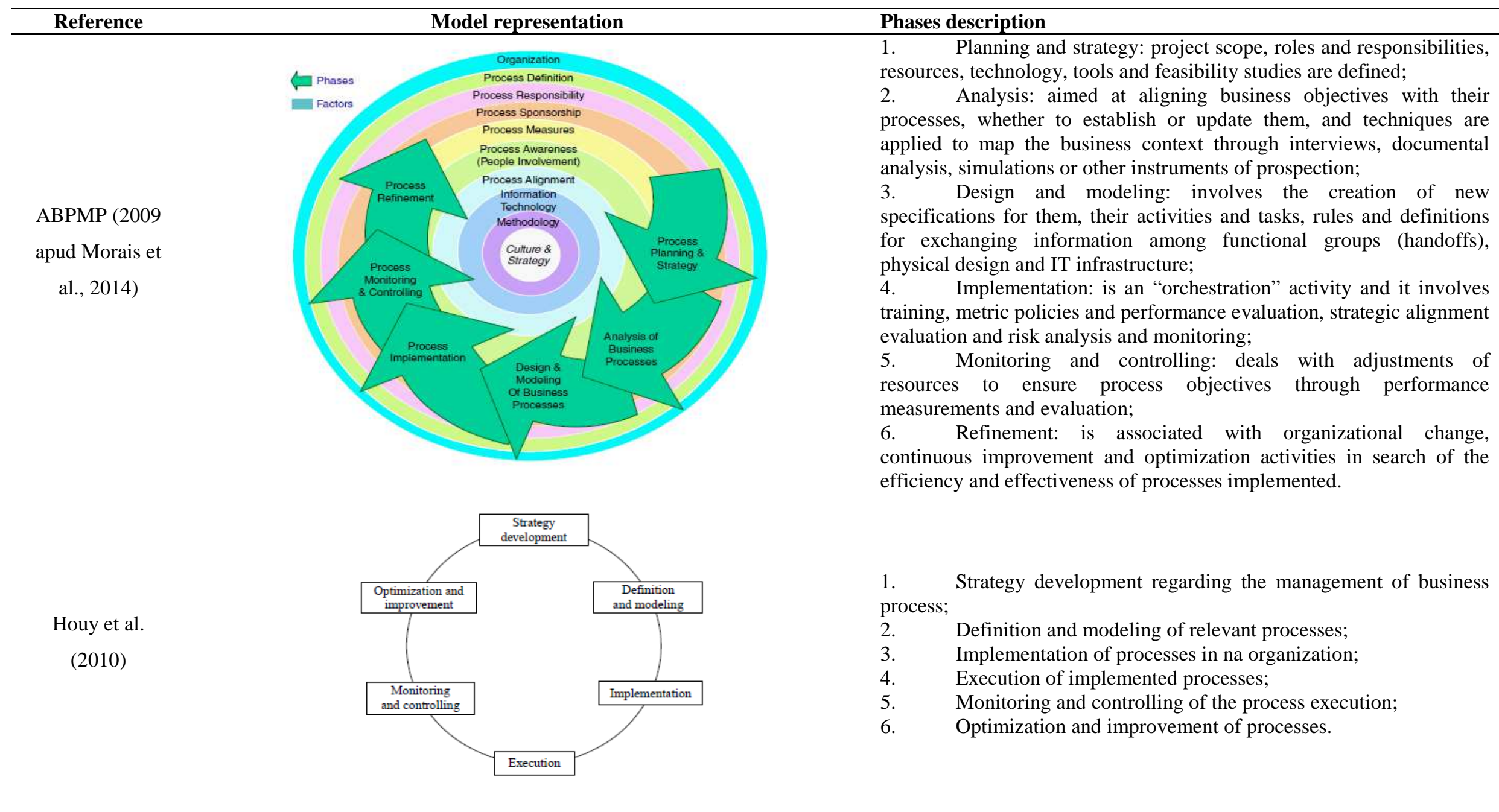




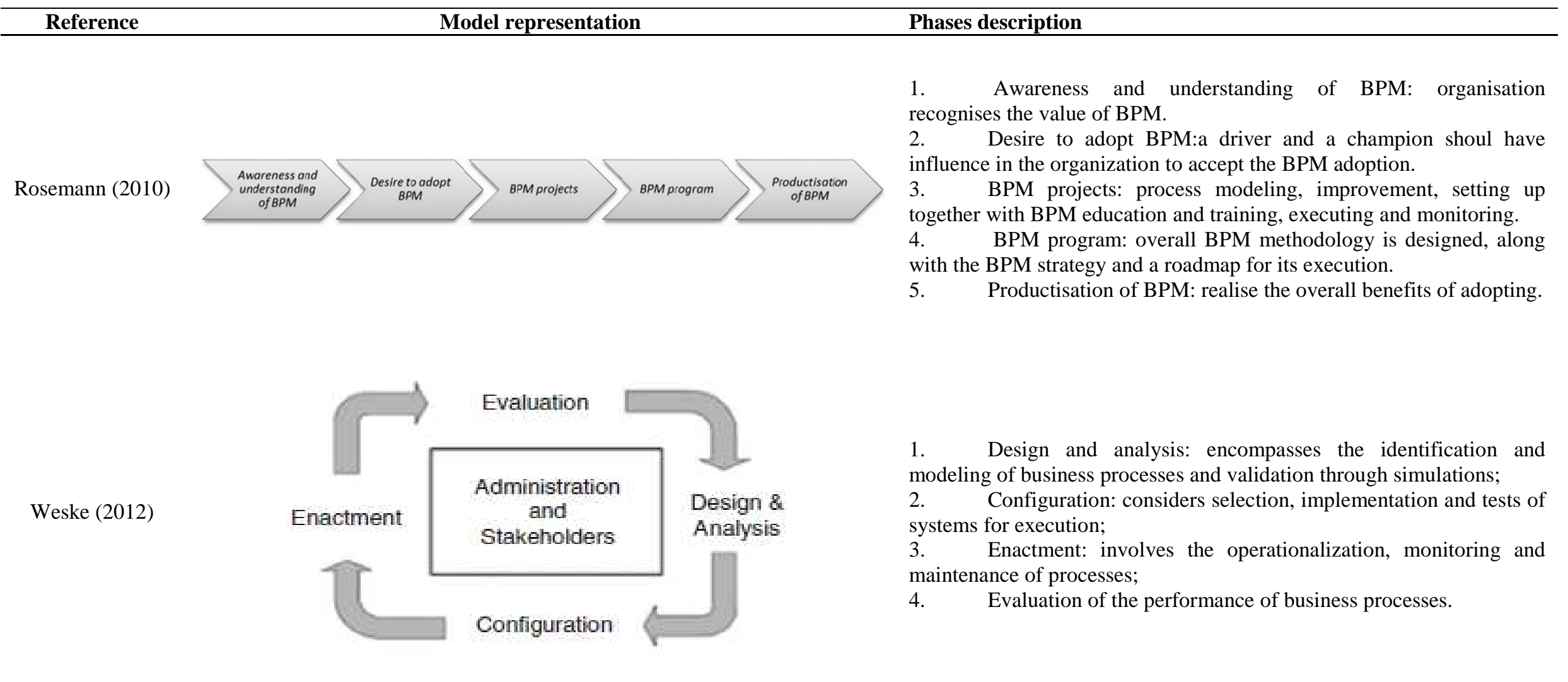




Reference

